\title{
Foreign Bank Entry and Credit Allocation in Emerging Markets
}

Hans Degryse, Olena Havrylchyk, Emilia Jurzyk, and Sylwester Kozak 



\title{
IMF Working Paper
}

Strategy, Policy, and Review Department

\section{Foreign Bank Entry and Credit Allocation in Emerging Markets ${ }^{1}$
Prepared by Hans Degryse, Olena Havrylchyk, Emilia Jurzyk, and Sylwester Kozak

Authorized for distribution by Lorenzo Giorgianni

December 2009

\begin{abstract}
This Working Paper should not be reported as representing the views of the IMF.

The views expressed in this Working Paper are those of the author(s) and do not necessarily represent those of the IMF or IMF policy. Working Papers describe research in progress by the author(s) and are published to elicit comments and to further debate.
\end{abstract}

We employ a unique data set containing bank-specific information to explore how foreign bank entry determines credit allocation in emerging markets. We investigate the impact of the mode of foreign entry (greenfield or takeover) on banks' portfolio allocation to borrowers with different degrees of informational transparency, as well as by maturities and currencies. The impact of foreign entry on credit allocation may stem from the superior performance of foreign entrants ("performance hypothesis"), or reflect borrower informational capture ("portfolio composition hypothesis"). Our results are broadly in line with the portfolio composition hypothesis, showing that borrower informational capture determines bank credit allocation.

\section{JEL Classification Numbers: G21, G28, G34, L11}

Keywords: banks, ownership, credit allocation

Author's E-Mail Address: h.degryse@uvt.nl, olena.havrylchyk@cepii.fr, ejurzyk@imf.org, Sylwester.Kozak@mail.nbp.pl

\footnotetext{
${ }^{1}$ The authors would like to thank Thorsten Beck, Stijn Claessens, Paul De Grauwe, Adam Glogowski, Marta Golajewska, Christa Hainz, Vasso Ioannidou, Matthias Koehler, Alina Luca, Daniel E. Nolle, Steven Ongena, Damiaan Persyn, Viorel Roscovan, Rajdeep Sengupta, Dobromil Serwa, Patrick Van Cayseele, Rudi Vander Vennet, Delia Velculescu, as well as participants at the XVI Tor Vergata, 2008 FMA, $6{ }^{\text {th }}$ INFINITI, 2009 FIRS conferences and seminars at the IMF, the NBP, CEPII, VU Amsterdam, and Tilburg University for many helpful comments and suggestions. The paper was completed while O. Havrylchyk and E. Jurzyk were visiting the NBP, whose hospitality is gratefully appreciated. Emilia Jurzyk acknowledges financial support from the Research Council of the KU Leuven, in the framework of Central and Eastern European Initiatives. Hans Degryse holds the TILEC-AFM Chair on financial market regulation. The remaining errors are the sole responsibility of the authors.
} 


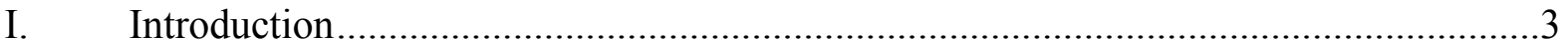

II. Literature Review: Theoretical Predictions and Empirical Evidence........................6

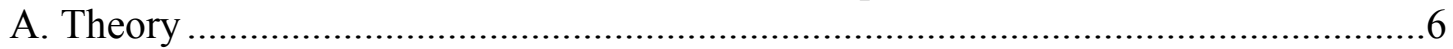

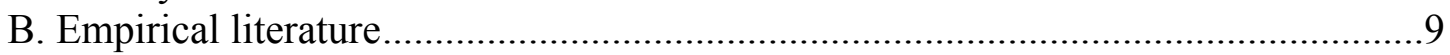

III. Data: Polish Banking Industry and Summary Statistics ......................................11

IV. Empirical Analysis_-Portfolio Allocation.......................................................14

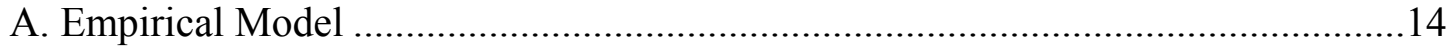

B. Results for Borrower Type-Portfolio Allocation..............................................16

C. Results for Loans at Different Maturities_-Portfolio Allocation.............................17

D. Results for Loans in Foreign Currency_Portfolio Allocation ...............................18

V. Empirical Analysis_Loan Rates.......................................................................19

A. Empirical Model ..................................................................................... 19

B. Results for the Average Bank Lending Rate...................................................19

C. Results for Borrower Types - Lending Rate.................................................20

D. Does Time Influence Lending Rates? ......................................................... 21

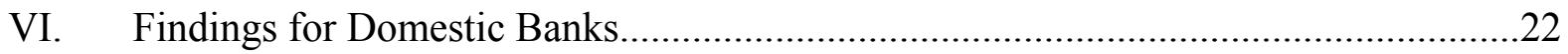

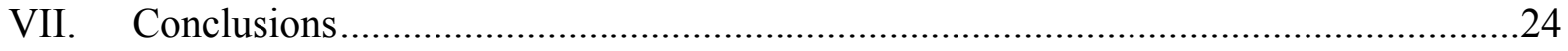

Tables

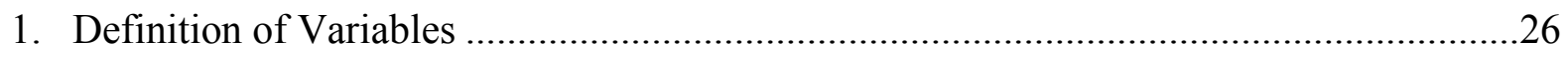

2. Summary Statistics............................................................................................2

3. Borrower Type: Share of Loans to Private Firms and Entrepreneurs..............................29

4. Loan Maturity: Share of Loans by Maturity in Banks' Portfolios...................................30

5. Foreign Currency: Share of Loan Portfolio in Foreign Currency .................................... 31

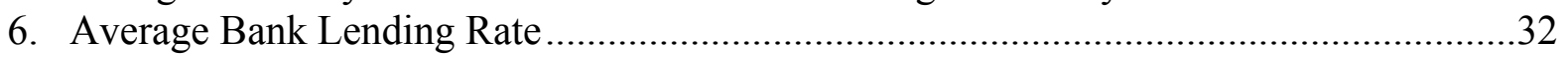

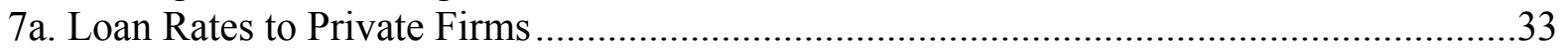

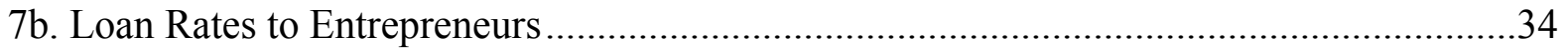

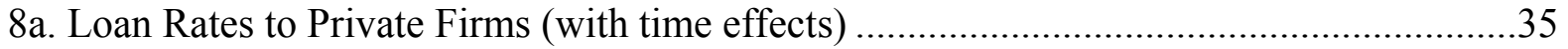

8b. Loan Rates to Entrepreneurs (with time effects) ...........................................................36

9. Domestic Banks: Share of Loans to Private Firms and Entrepreneurs ............................37

10. Domestic Banks: Nonperforming Loans for Private Firms and Entrepreneurs .................38

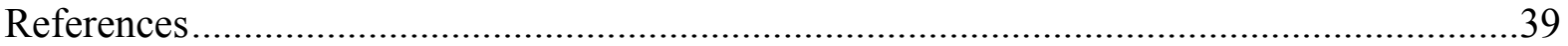




\section{INTRODUCTION}

Credit allocation is an important determinant of economic growth (see e.g., Levine, 2005). Recent theories predict considerable impacts of different modes of foreign bank entry on credit allocation. Foreign banks may overcome cross-border informational disadvantages when they are efficiently managed and have a superior performance (the "performance hypothesis"; see Berger and others., 2000). Foreign banks then extend loans to all borrower types, and charge lower lending rates than domestic banks (Martinez Peria and Mody, 2004; Claeys and Hainz, 2007). Foreign banks however are often accused of "cherry picking" the best borrowers, and in general, of lending more to large transparent firms at the expense of small and medium sized enterprises (SMEs), implying a different portfolio composition (the "portfolio composition" hypothesis; see e.g., Dell'Ariccia and Marquez, 2004; Sengupta, 2007; Claeys and Hainz, 2007; Gormley, 2007a; Detragiache and others., 2008). Also, foreign banks could have only short-term objectives in their host countries, making them less likely to extend long-term loans (Rodrik and Velasco, 1999). Finally, foreign banks may increase the supply of loans in foreign currency, which can be detrimental to the financial stability of the host country if the borrowers do not hedge this currency risk (Sorsa and others., 2007).

While there is a growing number of empirical studies analyzing lending to borrowers by foreign banks (see e.g., Berger and others., 2001; Clarke and others., 2005; Clarke and others., 2006; Gormley, 2007b; Giannetti and Ongena, 2008a,b), up to now, no comprehensive investigation of all dimensions of banks' credit allocation was possible due to lack of detailed data. Our unique data set containing bank-specific information on several dimensions of credit allocation allows for a detailed investigation of the theoretical predictions of foreign bank entry on credit allocation.

We study the impact of different modes of foreign bank entry (greenfield and takeover) on the supply of loans to transparent and opaque borrowers, as well as the impact on loan maturity, currency, and loan rates for these groups of borrowers. We also investigate the impacts of foreign bank entry on the portfolio composition and risks of domestic banks. We differentiate between greenfield banks (foreign banks that enter via greenfield investment) and takeover banks (foreign banks that acquire an existing domestic institution), because theory suggests that the impacts of foreign banks' behavior depends on their mode of entry (see e.g., Claeys and Hainz, 2007). Takeover banks for example may encounter difficulties when trying to improve credit standards or risk management procedures, as the acquired institutions are burdened by nonperforming loans and non-transparent organizational structure. Greenfield banks, while free of such concerns, are disadvantaged in their access to borrower information, whereas takeover banks possess relationships with incumbent firms they inherit from the acquired bank. 
An appropriate test of the impacts of different modes of foreign bank entry on credit allocation requires the presence of both an important fraction of foreign entrants and of domestic banks. Our unique detailed data set on the Polish banking industry fulfills this requirement, as currently the share of foreign investors in Polish banks amounts to 74 percent, and banks of all types of ownership and mode of entry are represented. The data set provides us with quarterly information on the portfolio composition of all Polish banks regarding different groups of borrowers, loan maturity, currency, and loan rates for the period 1996-2006. We believe that our paper is the first to study all dimensions of banks' credit allocation in a comprehensive way.

Our findings can be summarized as follows. First, we show that greenfield banks devote a higher share of their portfolios to transparent borrowers, lend more at shorter maturity and in foreign currency. Second, there is a significant convergence between foreign and domestic banks in terms of groups of borrowers they lend to, while there is no convergence in terms of maturity and currency, possibly stemming from foreign banks' refinancing possibilities. ${ }^{2}$ Third, we show that both modes of foreign bank entry had a detrimental impact on the loan portfolio quality of domestic banks. Finally, our findings support the "portfolio composition" hypothesis, and thus contradict studies that argue that greenfield banks charge lower lending rates than domestic private banks due to their superior performance only. Previous results in the literature could stem from the fact that greenfield banks have a higher share of the most transparent borrowers in their portfolio, whose cost of credit is lower than that of opaque borrowers. Moreover, earlier studies argue that there is a convergence of interest rates between banks of different types of ownership, whereas we show that this effect can be attributed to portfolio composition, as, with time, greenfield banks start lending less to transparent borrowers.

The effect of bank ownership on the cost of credit for different types of borrowers is an important question, since lending rates might be prohibitive for some borrowers, damaging economic growth. For example, Calvo and Coricelli (1993) argue that the credit contraction in Central and Eastern Europe explains partly the heavy decline in output in this region during the period 1989-90. Therefore, lower interest rates of foreign banks might speak in favor of removing entry barriers for foreign banks. However, it is important to examine whether foreign banks charge lower lending rates to all borrowers, or only to large transparent firms at the expense of opaque SMEs which may continue to suffer from the informational capture of incumbent banks. In most countries SMEs account for the majority of firms in the economy and a significant share of employment (Hallberg, 2001; Ayyagari and others., 2007), hence their access to financing has important implications for the level of economic development and growth. The existing empirical evidence shows that lending rates

\footnotetext{
${ }^{2}$ These results are obtained using different methodologies such as looking at different subperiods or using bank age.
} 
of foreign banks in developing countries are lower than those of domestic banks. This is particularly true for greenfield banks which are not burdened with nonperforming loans and inefficient organizational structures (Martinez Peria and Mody, 2004; Claeys and Hainz, 2007). We show that this empirical finding may stem from a portfolio composition effect in that foreign banks serve more transparent borrowers. Our findings are in line with Dell'Ariccia and Marquez (2004) and Sengupta (2007)'s theoretical models. Dell'Ariccia and Marquez (2004) argue that foreign banks have advantages in targeting more transparent new clients (transactions-based lending), whereas domestic banks are better placed to lend to firms based on soft information (relationship lending). Sengupta (2007) shows that foreign entrants may exploit their cost-advantage by offering collateralized loans to large transparent firms whereas incumbent banks retain more risky borrowers. Such market segmentation could lead to reduced access to finance of firms relying on domestic lenders (Gormley, 2007b). Giannetti and Ongena (2008b) show however that all firms benefit from foreign entry as indirect effects outweigh. ${ }^{3}$

The portfolio composition effect can additionally manifest itself in other dimensions of credit allocation such as collateral requirements (Sengupta, 2007), and the maturity and currency denomination of loans. In recent years, loans in foreign currencies gained popularity in some emerging economies due to their perceived lower costs (Brown and others., 2008). Indeed, loan rates in domestic currencies have been higher than the ones in foreign currencies in most transition economies, and borrowers - willing to take on foreign exchange and interest rate risks - preferred to take loans denominated in foreign currencies. In some countries appreciation of the domestic currency made loans in foreign currency appear even cheaper. Foreign banks also supplied more easily foreign currency loans, since they have better access to international capital markets and to financing from their parent institutions. Further, foreign bank lending may involve more short-term loans to solve asymmetric information problems as wells as "hot" money that is readily retracted during crises. ${ }^{4}$ We therefore also study how the mode of foreign bank entry impacts the maturity and currency denomination of loans, as well as the impact of maturity and currency denomination on the lending rate.

The rest of this paper is organized as follows. Section II reviews the theoretical predictions and empirical evidence. Readers who are interested in our results only, can directly go to Section III where we present our data and summary statistics. Sections IV and V describe our empirical findings on portfolio allocation and loan rates, respectively. Section VI deals with the impacts of foreign entry on domestic banks. Section VII concludes.

\footnotetext{
${ }^{3}$ There is also some empirical evidence showing that foreign-owned banks are less likely to lend to informationally opaque small businesses than domestically-owned banks (Berger and others, 2001; Clarke and others, 2006, Gormley, 2007b, Mian, 2006).

${ }^{4}$ For example, Dooley and Shin (2000) argue that foreign creditors' run from Korean banks triggered the crisis in Korea in 1997.
} 


\section{Literature Review: Theoretical Predictions and Empirical Evidence}

\section{A. Theory}

Theory predicts different impacts of foreign bank entry on credit allocation. We start with the impacts on banks' portfolio allocation and loan rates to transparent and opaque

borrowers. Berger and others. (2000) formulates the global advantage hypothesis, according to which efficiently managed foreign institutions are able to overcome cross-border disadvantages (distance, monitoring costs, differences in institutional environment, language and culture) and operate more efficiently than their domestic competitors. Foreign banks may have higher efficiency when operating in other nations as they are able to spread their superior managerial skills or best-practice policies and procedures over more resources, thus lowering costs. ${ }^{5}$ We label this the "performance hypothesis". The "performance" effect is expected to be identical for all borrowers when foreign entrants pass on the efficiency gains in a similar fashion to both transparent and opaque borrowers. ${ }^{6}$ The performance hypothesis should be strongest for foreign banks entering transition economies that have nascent banking markets characterized by low competition and efficiency, and for greenfield banks relative to takeover banks as the first type did not inherit bad loans and inefficient organizational structures. Takeover banks in contrast need transitional time in order to modernize their lending practices and to clean up the loan portfolio which is left from previous owners.

An alternative hypothesis explaining banks' choices of clients can be labeled the "portfolio composition hypothesis". Several theoretical papers argue that foreign banks have a comparative advantage in lending based on hard information, i.e., in lending to large transparent firms that have a long credit history and detailed financial statement information (Dell'Ariccia and Marquez, 2004; Gormley, 2007a; Gormley, 2007b; Sengupta, 2007; Detragiache and others., 2008). Moreover, foreign banks are better suited to lend to multinational corporations from their home countries. In contrast, domestic banks use "relationship lending" to gain knowledge about opaque firms that can produce less hard

\footnotetext{
${ }^{5}$ Foreign entrants may also raise revenues through superior investment or risk management skills, by providing better service quality/variety that some customers prefer, or by obtaining diversification of risks that allows them to undertake higher risk-higher expected return investments. Further, foreign banks in transition and developing economies additionally benefit from their better access to international capital markets and funding from their parent companies. This diminishes their cost of funds, which in turn should be translated into lower lending rates, benefiting borrowers. Moreover, foreign banks might enjoy lower cost of deposits due to their superior reputation.
}

${ }^{6}$ The following empirical papers show that foreign banks exhibit indeed higher efficiency (Bonin and others, 2005; Weill, 2003), experience faster and more stable loan growth (De Haas and Lelyveld, 2006), and enjoy higher profitability than domestic banks (Havrylchyk and Jurzyk, 2007). 
information about the quality of the firm, but can provide soft information (Berger and others., 2001). ${ }^{7}$

Besides having a disadvantage in using soft information, foreign banks, and in particular greenfield institutions, might be less willing to do so. This idea is modeled by Stein (2002) and introduced into the banking literature by Berger and others. (2005). Stein (2002) argues that organizations with more hierarchical structures are more likely to rely on hard information as opposed to organizations with flatter structures. The reason is that flatter organizations have better control and information on their managers, and thus can afford to give them more discretion, which allows them to use soft information. The modeling in Stein (2002) and Berger and others. (2005) can be easily applied to foreign entrants, which are usually part of large multinational banking groups, and where communication of soft information is obstructed not only by the hierarchy, but also by cultural and linguistic barriers. We can also assume that funds are more easily moved to/from greenfield institutions than to/from takeover banks that have large deposit networks and are thus more independent in their financing. This would additionally diminish the incentives of managers of greenfield institutions to invest time in gathering soft information and engaging in relationship lending. ${ }^{8}$

Dell'Ariccia and Marquez (2004) also demonstrate the impacts on loan rates when foreign entrants compete with better informed domestic banks. They show that loan rates charged to transparent borrowers are lower than those charged to opaque clients, and this is due to differences in the borrowers' elasticity of demand for credit. Transparent borrowers have a more elastic demand because they can signal their information to outside lenders, which leads to higher competition and, thus, lower cost of funds for large transparent firms. Opaque firms, on the other hand, cannot signal their worth and are captured by their creditors leading to higher borrowing costs for them.

\footnotetext{
${ }^{7}$ Hard and soft information differ in their degree of transferability. Hard information refers to credible and publicly verifiable data, such as firms' balance sheets, credit history, collateral and guarantees. Soft information cannot be verified by a third person and is gained a result of the relationship between a bank and a borrower. For example, through repeated interviews with an owner of a young firm, a bank manager might be convinced that the firm's owner is a smart, honest and hard working entrepreneur with a high probability of success. However, this soft information cannot be transferred to other potential lenders (Petersen, 2004).

${ }^{8}$ New studies question the argument that large and foreign banks are not capable to lend to SMEs (Berger and Udell, 2006; de la Torre and others., 2008). The reasoning is that latest advances in credit scoring methodologies coupled with enhanced computer power and increased data availability make transaction lending technologies to be well suited for funding small firms (Mester, 1997; Petersen and Rajan, 2002). This is especially true when credit scores are based on the owner's personal consumer data obtained from consumer credit bureaus, which is combined with data on the SME collected by the financial institutions. These studies still agree that small domestic banks have an advantage to gather and process soft information, but they argue that large and foreign banks are also able to lend to SMEs, but using "hard" information-based technologies. In this case, we should not observe differences in portfolio allocations of loans between different types of banks.
} 
The above two results - the fact that foreign banks would prefer to lend to more transparent borrowers and that lending rates for this type of client are lower-could explain the negative impact of foreign bank ownership on lending rates. Claeys and Hainz (2007) model the impact of different modes of foreign bank entry when competing with domestic banks. Greenfield and takeover banks both enjoy superior screening technology whereas only takeover banks enjoy access to soft information. Domestic banks then have to shade their bids more when competing with takeover banks than with greenfield banks. Their model then predicts that greenfield banks charge lower loan rates than takeover banks for opaque borrowers. Further, greenfield banks will aim to shy away from opaque borrowers for whom soft information is important.

Foreign entry could also impact loan maturity and currency composition. Foreign banks might bring in hot money, which can be easily withdrawn in case of crisis (Rodrik and Velasco, 1999). Foreign banks may also use shorter loan maturities to mitigate borrower risk and asymmetric information (Ortiz-Molina and Penas, 2008). The theoretical impact of loan maturity on cost of credit is ambiguous as it reflects two opposite effects. A borrower that issues short-term debt can face costly liquidations at expiration which motivates it to opt for longer-term debt. At the same time, lenders prefer to give short term loans because of agency problems, such as asset substitution and underinvestment. As a result, borrowers are willing to incur and lenders demand higher lending rates for loans with longer maturity.

Alternatively, lenders might ration credit to risky borrowers and force them to take shortterm loans, which would decrease average lending rates on long-term loans. Empirical evidence supports both hypotheses for corporate loans and bonds (Gottesman and Roberts, 2004; Helwege and Turner, 1999). For an individual firm, the spread typically increases with maturity, reflecting greater uncertainty. At the same time, safer firms tend to issue longerdated bonds or have access to long-term bank credit, which causes the average spread to decline with maturity. ${ }^{9}$

The currency composition of loan portfolios can also be influenced by the entry of foreign banks (Sorsa and others., 2007), because ability and willingness of banks to supply loans in foreign currency depends primarily on their access to foreign funds and/or on hedging

\footnotetext{
${ }^{9}$ The situation in our data set (i.e., Poland) is additionally complicated because yield curves were downwardsloping till 2003, reflecting market expectations of diminishing inflation and interest rated convergence to the EU level. Short-term interest rates declined dramatically from $20.6 \%$ at the end of 1996 till $5.7 \%$ in 2003, with a yield curve taking an upward shape after 2003. In such economic environment, firms would agree to take long-term loans only if they had lower interest rate than short-term ones. It should be noted that this situation was not unique and is still observed in some CEECs.
} 
opportunities. ${ }^{10}$ In this respect, foreign banks have an advantage over domestically-owned banks, since they enjoy better access to international capital markets, including their own parent banks. ${ }^{11}$ Currency composition may also be an important determinant of lending rates. In fact the popularity of loans denominated in foreign currencies stems from lower lending rates that are charged on this type of loans. Brown and others. (2008) for example show that opaque firms have an additional incentive to declare that their revenues are in foreign currency in order to profit from cheaper cost of credit. This interest rate advantage can be considered as a compensation for the inherent foreign exchange risk. For instance, Beer and others. (2008) find that more risk-loving households are more likely to take a loan in a foreign currency. However, a survey undertaken in 11 CEECs shows that most borrowers, particularly households and SMEs, are not aware of involved currency risk (ECB, 2006). This is due to historically low exchange rate volatility in some countries, which created a belief in low foreign exchange rate risk. The willingness to borrow in foreign currency is additionally enhanced by appreciation of the local currency, which is also true for Poland.

To sum up, we expect that loan maturity and currency could be substantially different across banks with different ownership and could play an important role in explaining lending costs. Since foreign banks are more likely to lend short term and in foreign currency, we will also have to control for these portfolio characteristics in order to distinguish between the performance and portfolio composition hypotheses.

\section{B. Empirical literature}

The empirical evidence on foreign-owned banks and SME credit availability in developing countries is rather inconclusive. Studies that focus on foreign bank entry and lending to SMEs in CEECs do not provide direct evidence of whether foreign banks' lending is biased towards large transparent borrowers. De Haas and Naaborg (2006) conduct focused interviews with managers of foreign parent banks and their affiliates in Central and Eastern Europe and document that foreign banks expanded into SME and retail markets. Giannetti and Ongena (2008a) use firm level data and find that foreign bank presence in Central and Eastern Europe stimulates growth of financial loans, and even though large firms benefit more from foreign lending, smaller companies profit as well. But it is not clear whether loans

\footnotetext{
${ }^{10}$ Very often loans that are contracted in foreign currency are actually extended to borrowers in domestic currency, even though they have all the characteristics of foreign currency loans, namely interest rate and exchange rate risks. In this case banks are not obliged to have access to foreign currency funding, but rather they should be able to hedge their exposure to foreign currency risk, which is easiest for banks with good standing on international financial markets.

11 To illustrate this point in our sample, the share of interbank liabilities of greenfield banks from nonresident banks has increased from 7 to 20 percent of total banks' assets, reflecting an increasing attractiveness of Poland for foreign investors. At the same time, the share of nonresident interbank liabilities of domestic banks, both private and state-owned, was virtually zero.
} 
to SMEs are supplied by foreign banks or whether domestic institutions decided to expand to this sector because of increased competition in the market for transparent borrowers.

Many empirical studies on foreign bank entry focus on Latin American countries. Berger and others. (2001) find that foreign-owned institutions have difficulties extending loans to opaque small firms in Argentina, particularly when foreign banks come from far-away countries. Interestingly, banks that are headquartered in other Latin American countries do not differ in their lending practices from domestic banks. Clarke and others. (2006) find that foreign banks in Chile and Peru lend less to SMEs than domestic private banks, whereas the difference is not significant in Argentina and Colombia. They also find that large foreign banks increase their lending to SMEs faster than domestic banks.

Studies that focus on Asian markets come up with even more pessimistic conclusions. Mian (2006) finds that greater cultural and geographical distance between foreign banks' headquarters and local branches in Pakistan leads them to avoid lending to "informationally difficult" but sound firms that require relationship lending. Gormley (2007b) finds that only profitable firms benefit from foreign bank entry in India, whereas there is a significant drop in loans to informationally opaque firms.

Unlike above country studies, Clarke and others. (2006) rely on a firm survey conducted in 35 developing and transition economies. They conclude that SMEs benefited from foreign bank entry in the form of lower financing obstacles. However, they cannot determine whether this improvement came thanks to more lending by foreign institutions, or whether domestic banks increased their lending to SMEs because of the increased competition on the market for large transparent borrowers. Moreover, their study suffers from the lack of time series dimension, which does not allow them to analyze the observed impact over time. Giannetti and Ongena (2008b) find for a set of emerging countries that relationships with foreign banks are less likely to be terminated. Further they also show that firms benefit indirectly from the presence of foreign investors as it increases the probability that firms establish bank relationships, improving access to credit for all firms. And Detragiache and others. (2008) find for a set of 89 middle and low income countries that countries with a larger foreign bank presence have shallower credit markets and exhibit slower credit growth with a larger initial foreign bank presence.

Most of empirical studies for developing and transition countries show that greenfield banks charge lower lending rates and spreads than domestic banks and takeover banks. Martinez Peria and Mody (2004) study banking markets in five Latin American countries during the late 1990s and find that foreign banks have lower spreads than domestic banks and takeover banks have higher spreads than greenfield banks. Claeys and Hainz (2007) document that greenfield banks charge the lowest lending rates in ten CEECs. However, absence of sufficiently detailed data does not allow them to discriminate between the two main 
complementary hypotheses we discussed above, i.e., the performance hypothesis and the portfolio composition hypothesis.

\section{Data: POlish Banking Industry AND Summary STAtistics}

We test our hypotheses using a unique data set that was kindly provided by the National Bank of Poland. It contains quarterly information on 110 Polish banks ${ }^{12}$ between December 1996 and December 2006. In addition to standard information from balance sheets and income statements (like bank assets, capitalization, costs and profits), it contains data on interest income, amount of granted loans, and nonperforming loans for two borrower types: private firms and individual entrepreneurs. ${ }^{13}$ Our data give us a unique opportunity to construct banks' portfolio shares, interest rates, market shares, concentration measures (Herfindahl index), and nonperforming loans for each borrower type separately.

The distinction between the two groups of borrowers mentioned above is grounded in Polish law. A borrower is classified as a "private firm" if the firm is owned by private investors (either entirely, or where the private share exceeds 50\%), and is either subject to commercial law or is subject to civil law and employs more than 9 workers. Additionally, such firms have to comply with accounting regulations that require full bookkeeping. "Individual entrepreneurs (for short, entrepreneurs)", in contrast, are small firms employing up to 9 workers, subject to civil law, and using simplified accounting procedures.

In theory, transparent firms have reliable financial statements, long credit history, and good collateral, all of which help the bank to evaluate borrower's creditworthiness. We are confident that private firms in our sample correspond to this definition; hence we label them also as transparent borrowers. ${ }^{14}$ We classify entrepreneurs as opaque because they are small and often young entities, and that makes it more challenging for a bank to judge their capacity and willingness to repay. This is particularly acute in emerging markets, where many small firms are informal. It implies that a firm might have larger turnover and assets than it declares officially, but it also implies that the firm has unrecorded, contingent senior liabilities to its employees (de la Torre and others., 2008).

\footnotetext{
${ }^{12}$ We define a bank as Polish if it is registered in Poland and the National Bank of Poland collects information on it.

${ }^{13}$ We have information on three other groups of borrowers, namely state-owned enterprises, individuals, and farmers. Due to the difficulties in classifying these borrowers in terms of transparency, we decided to use only the two groups mentioned in the text.

${ }^{14}$ Most private firms have considerably more than 9 workers as firms have a tendency to stay either below or go far above this cutoff. The average statistics therefore are clearly driven by large firms.
} 
The Polish banking sector provides a good testing ground for our hypotheses because, similar to other CEECs, it experienced massive foreign direct investments into the banking sector. At the end of 2006, the share of foreign investors in Polish banking constituted 74 percent. This is less, however, than in other major CEECs - for example in Hungary more than 80 percent of banking assets is in foreign hands, and in the Czech Republic and Slovakia foreign banks control more than 95 percent of assets. The relatively smaller presence of foreign banks in Poland gives us an additional strong argument to use Poland as a case study, since there are still local private and state-owned banks left which serve as a benchmark.

During 1996-2006, there were a number of domestic mergers and acquisitions in the Polish banking sector, hence we treat merged institutions as two before the merger and as one afterwards ${ }^{15}$. For our estimations we have deleted the first four quarters of operations for both greenfield and takeover banks in order to exclude the initial setting-up and transformation period.

Tables 1 and 2 present variable definitions and summary statistics for the variables that we employ in our analysis, respectively. Let us look first at the composition of banks' portfolios. As predicted by the portfolio composition theory, foreign banks extend their loans predominantly to transparent borrowers: on average, these loans constitute 54 percent of the total portfolio. At the same time, domestic banks focus much less on transparent firms - they constitute only 31 percent of their portfolio, and the difference between the two is statistically significant. The mode of entry plays a very significant role too, as greenfield banks extended almost $67 \%$ of their loans to private firms, which is 25 percentage points more than takeover banks, and twice as much as domestic banks, both private and public. Domestic private banks, on the other hand, appear to possess a comparative advantage in lending to opaque borrowers, i.e., entrepreneurs. Our data show that they devote $15 \%$ of their portfolio to these borrowers, which is one and a half times more than other banks.

The differences in banks' portfolios are not constant over 1996-2006. First, it is interesting to note that greenfield banks over time start lending more to entrepreneurs, and this stands in contrast to the behavior of all other banks. In the same time, they decrease the share of loans to private firms in their portfolio. It seems, therefore, that greenfield banks over time acquire skills needed for lending based on soft information. Alternatively, we could hypothesize that they implement methodologies used for assessment of hard information provided by their large clients for the purposes of lending to SMEs, in spirit of Berger and others. (2001).

\footnotetext{
${ }^{15}$ We also investigated the effect of domestic mergers on banks' lending rates by including a dummy that takes a value of one if the bank had undergone a domestic merger, and zero otherwise. Our estimations revealed that this merger dummy was never statistically significant and, therefore, we decided to exclude it from our final results.
} 
The summary statistics reveal that loan maturity differs according to the mode of foreign entry. Greenfield banks issue more and takeover banks less short-term loans than domestic private banks (53, 36 and 41 percent, respectively). At the same time, public banks extend more long-term loans than any other type of bank, followed by takeover banks. This might be explained by less stringent portfolio management techniques and their lower volatility of deposits due to implicit government guarantees. It is interesting to see that, contrary to the findings for borrower type, the differences between banks with respect to loan maturity are persistent over our sample period. While all banks eventually start granting more long-term loans, the share is still the highest for public banks, while greenfield banks held the highest stare of short-term loans.

We now turn to the currency composition of loan portfolios for different types of banks. One of the characteristics of many CEECs is the high proportion of loans in foreign currency. Their share ranges from around 10-20 percent in Czech Republic and Slovakia, to 6070 percent in the Baltic States. As we see in the data, in 2006 Polish banks extended 23 percent of their loans in foreign currency, which is not very high in comparison to other countries. Still, this poses significant risks for the banking sector, as many borrowers, especially the SMEs, are not hedged against currency and interest rate risk. ${ }^{16}$ As expected, foreign banks, particularly greenfield institutions, give more loans in foreign currency than domestic banks, which is probably due to their better access to international capital markets and parent companies. These differences are persistent over our sample period.

A comparison of loan rates across all bank types reveals that greenfield banks charge the lowest loan rates: 14.7 percent on average for all borrowers, whereas private domestic banks charge the highest: 21.7 percent. Takeover banks offer lower lending rates than both types of domestic banks, but charge more than greenfield institutions. These results are in line with the existing literature. We also test the differences in rates of greenfield, takeover, and stateowned banks with respect to rates charged by domestic private banks, and find that all the differences are statistically significant.

Next, we compare rates on loans to different types of borrowers. Lending rates offered to private firms - the most transparent borrowers - are significantly lower than lending rates charged to entrepreneurs. The difference between them is 2.3 percentage points on average and is statistically significant. This is in line with the theoretical considerations that lending rates in the competitive markets with the smallest informational asymmetries should be the

\footnotetext{
${ }^{16}$ Many foreign currency loans are extended in Swiss Francs, on which lending rates are lower than on Euro loans. This characteristic is shared by other countries in CEECs, such as Hungary and Slovenia. This trend comes from Austria where most of loans in foreign currency are denominated in Swiss Franc. Originally this was constrained to regions bordering Switzerland where firms and individuals had a natural hedge against currency risk since their income was often in Swiss Franc. However, lending in Swiss Francs is now extended to other parts of Austria and to CEECs where Austrian banks are active.
} 
lowest whereas lending rates for opaque borrowers are the highest due to high switching costs stemming from informational asymmetries. ${ }^{17}$

\section{Empirical Analysis-Portfolio Allocation}

\section{A. Empirical Model}

We first study the impact of foreign entry and bank ownership on the allocation of loans with respect to borrower type, maturity and currency. We model banks' portfolio shares as a function of ownership and mode of entry, as well as controls for bank characteristics, macroeconomic environment, and market structure.

To be more formal, we estimate the following model for different types of borrowers, maturities and currency:

$$
\begin{aligned}
& \ln \left(\frac{P_{i t}}{1-P_{i t}}\right)=\alpha_{0}+\alpha_{1} \text { Ownership }_{i t-1}+\alpha_{2} \text { Bank }_{\text {character } \dot{s i c s}} \text { Bt }-1+\alpha_{3} \text { Macro }_{t-1}+ \\
& +\alpha_{4} \text { Market Structure }_{i t-1}+\text { Season }_{t}+\varepsilon_{i t},
\end{aligned}
$$

where $P_{i t}$ is the share of loans: by borrower, by maturity, or by currency in loan portfolio of

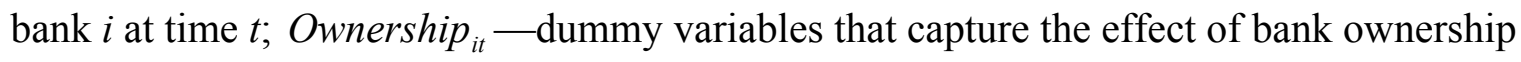
(State-owned) and mode of foreign bank entry (Takeover and Greenfield) for bank $i$ at time $t$; Bank characteristics $_{i t}$ - variables that control for return on assets (ROA), Capitalization, Costs, and the share of nonperforming loans (NPL) in the portfolio of bank $i$ at $t$; Macro variables that control for Inflation, real short-term interest rate (Real interest rate) and real GDP growth $(G D P)$ at $t$; Market Structure $_{i t}$ — variables that control for bank size (Bank size) at time $t$. We lag all explanatory variables by one period and also include seasonal dummies.

Following Berger and others. (1998) and Clarke and others. (2006) we estimate all share equations in log-odds logit form which allows us to get around the problem that shares by definition are bounded between 0 and 1 . Since our data set is in panel version, initially we have to choose between panel and pooled estimation methods. The former, however, presents significant problems: while the Hausman tests indicates that we should allow for unobserved fixed effects in the error term, fixed effects estimation does not allow us to estimate the time-

\footnotetext{
${ }^{17}$ While there was a general trend for all lending rates to decrease over 1996-2006, the spread between lending rates to private firms and entrepreneurs has not changed in a significant way. Two countervailing forces may lead to this finding: opaque borrowers may have become more transparent and foreign banks may have increased competition more in the transparent segment of the market.
} 
invariant coefficients (i.e., effect of greenfield ownership). ${ }^{18}$ Random effects estimation however will produce inconsistent parameter estimates. Consequently, we opt for a pooled model with clustered error terms. We also check the robustness of our results by estimating our regressions using Beck and Katz (1995) panel-corrected standard errors methodology, allowing for heterogeneity and autoregressive process of order 1 in the standard errors. Our results reported below are robust to this procedure and are available upon request. ${ }^{19}$

Our main variables of interest are three dummy variables that correspond to types of ownership and modes of entry (state-owned, greenfield, takeover), while private domestic banks serve the role of benchmark for our estimation. We also split these dummy variables for two periods - before and after 2001 - to capture changes in lending over time. As the choice of this threshold might appear arbitrary, we check the robustness of our results with other thresholds, but our findings remain unchanged. We believe that time period in which foreign banks operates is more important than banks' age. For example, a foreign bank that enters Poland in the later period is likely to have already been present in other Central and Eastern European countries, and therefore has at that time already a lot of experience in operating in a transition economy. In fact, we noticed that banks that were the first ones to enter Polish banking markets in the early 90s are also those that lend most to large firms, which reflects the fact that they came to Poland following their clients and were not interested in the local market.

As bank-level characteristics, we include ROA, Capitalization, Costs, Bank size and NPL (nonperforming loans) to capture the financial health and performance of banks, which might be correlated with bank strategies. We admit that these variables might be endogenous, even though we have lagged them. To further overcome this potential endogeneity problem we test the robustness of our results by including initial sample values of bank-characteristics, which does not change our main results in a significant manner. However, we prefer to present results with lagged bank characteristics, because they are time-varying and, thus, serve as better controls. It is important to note, though, that we do not attempt to rely on these variables to explain the causal relationship between bank characteristics and loan growth.

The expected signs for these bank controls are unclear because of conflicting hypotheses. Healthier banks with higher profits, better loan quality and higher capitalization might be able to grow faster over time and to expand to areas where it takes time and effort to acquire know-how of the business, like lending to SMEs. Similarly, healthier banks should be able to

\footnotetext{
${ }^{18} \mathrm{We}$ also check the robustness of results by applying the fixed effect vector decomposition procedure using three stage fixed effects methodology of Pluemper and Troeger (2007) and our coefficients of interest remain robust.

${ }^{19}$ We also test for nonstationarity of the banks' interest rate data using panel unit root tests of Levin, Lin and Chia-Shang (2002), Im, Pesaran and Shin (2003), Maddala and Wu (1999) and Hadri (2000). The null hypotheses for the first three tests are the existence of the unit root, whereas Hadri (2000) tests the null hypotheses of stationarity of time series. We find that all time series in the sample are stationary.
} 
extend more foreign currency loans and loans at longer maturity, because they have better access to foreign and long-term funding. On the other hand, banks that suffer from financial distress can be required by government supervisors, depositors, and capital market investors to reduce their risk profile. This would lead to a decrease in relationship lending to informationally opaque small businesses because the risk of these loans cannot be easily verified (Berger and others., 2001). Hainz (2005), in contrast, argues that firms can more easily switch from distressed banks as asymmetric information problems are lowered. Similarly, regulators might ask distressed banks to reduce their lending in foreign currency to reduce their currency risk. Therefore, we might expect a positive relationship between bank health and the share of loans to opaque clients, at longer maturity and in foreign currency.

Contrary to the above hypothesis, failing banks might be more willing to "gamble for resurrection" and lend to riskier borrowers, such as SMEs (Clarke and others., 2006). Moreover, large firms might be less willing to continue their relationship with such banks, whereas opaque clients might have more difficulties switching to other lenders, and distressed banks might benefit from their "captured" clients. They might also be more willing to lend in foreign currency disregarding currency risk considerations.

It should be mentioned that some of our bank-level variables, such as $R O A$, Costs, Capitalization, and Bank size, are calculated at the bank level, whereas nonperforming loans $(N P L)$ are calculated both at a bank and at a bank-portfolio level, i.e., separately for entrepreneurs and large firms. In the first case, we control for the general health of the bank, whereas in the second case we talk about the health of the particular part of a loan portfolio.

To control for macroeconomic environment, we include real short-term interest rate (Real interest rate), inflation rate (Inflation) and real GDP growth $(G D P)$. In general, we expect that periods of high economic growth with low interest rates and low inflation should be more beneficial for riskier and opaque clients, such as small entrepreneurs. Benign economic conditions should also increase lending in domestic currency and at longer maturity.

\section{B. Results for Borrower Type-Portfolio Allocation}

We first estimate the impact of foreign bank ownership on borrower composition of bank portfolios (share regressions). The results are reported in Table 3: columns 1-2 present findings with the share of private firms in the bank portfolios as dependent variable, and columns 3-4 with the share of entrepreneurs. The key explanatory variables in these regressions are the greenfield and takeover dummies, which we additionally split for the period before and after 2001 to analyze changes over time. Our findings show that, controlling for other factors, foreign banks that entered via greenfield investment devote almost 25 percent less of their portfolio to entrepreneurs (column 3) while they lend over 90 percent more to private firms (column 1) than domestic private banks. This result supports the portfolio composition theory that points to comparative disadvantages of foreign banks in lending to opaque clients. It is interesting to note, however, that the takeover dummy is not 
statistically significant. That can be interpreted as a sign that these disadvantages can be overcome by foreign banks if they take over existing institutions and thus acquire access to local knowledge via local personnel and existing relationships with firms.

To investigate convergence, we split our takeover and greenfield variables separately into dummies that take the value of 1 if bank was newly established (for greenfield) or acquired (for takeover) before 2001, and banks that entered (or were acquired) after that date. We do find that there is a convergence between banks in terms of portfolio composition as differences between greenfield and domestic private banks diminish after 2001 (columns 2 and 4). Even though greenfield banks still lend a larger share of their portfolios to private firms than domestic private banks, this share is smaller than in the first half of the period in a statistically significant manner. At the same time, the difference in terms of loans to entrepreneurs between greenfield and domestic private banks disappears after 2001. These findings reflect growing interest of greenfield banks in lending to SME, which may be brought by two main developments: 1) fierce competition in the credit market for large corporations and 2) improved ability of foreign banks' subsidiaries to finance relatively opaque SMEs (De Haas and Naaborg, 2006). Even though greenfield banks were still less able and less willing to engage in relationship lending, they developed other technologies that helped them to overcome opaqueness of entrepreneurs, such as small business credit scoring, asset-based lending, or fixed assets lending. They were able to do this in the later period, as legal and accounting systems have become more sophisticated, making some SMEs more transparent.

Our summary statistics suggested that takeover and state-owned banks also devote a smaller share of their portfolios to entrepreneurs than domestic private banks; however this result disappears in regressions when taking into account our control variables. This stems from the fact that these banks are usually large institutions, and their inability to lend to opaque clients is captured by the size variable. Our estimation results clearly show that larger banks prefer to lend more to private firms, whereas small banks are better at lending to entrepreneurs. As to other bank-specific variables, we find that a bank decreases the share of loans to a specific borrower type if the nonperforming loans (NPL) in its loan portfolio for that borrower type increase.

\section{Results for Loans at Different Maturities_-Portfolio Allocation}

The results of share regressions for loan portfolios at different maturities are reported in Table 4. We find that, controlling for other factors, greenfield banks lend more at short-term (up to one year), and less at long-term (over 5 years) than domestic private banks. The numbers are economically significant too, as the greenfield banks have over 73 percent more of short-term, and over 26 percent less of long-term loans in their portfolios than domestic private banks. These results are stable over time, and we do not observe substantial convergence in terms of portfolio maturity between banks. Even though the coefficients in the second half of the period appear to be smaller for short-term loans and larger for long- 
term loans, these differences are not statistically significant. Our findings suggest that only foreign banks that enter via greenfield investment prefer to lend short term, as there are no differences between takeover and domestic private banks (the base case).

Our results also show that low inflation and low real interest rates contribute to higher share of long-term loans, which is explained by higher certainty of business conditions and better possibilities of long-term planning, and higher precision of forecasting. We also find that healthier banks (measured by higher profits, smaller nonperforming loans, and higher capitalization) lend less short-term and more long-term.

\section{Results for Loans in Foreign Currency—Portfolio Allocation}

Table 5 reports the results of our portfolio share regressions for loans in foreign currency. We find that greenfield banks offer a higher share of loans in foreign currency. This result holds for the entire analyzed period - the difference in coefficients for greenfield banks before and after 2001 is not statistically significant (model 2).

The higher share of foreign currency loans granted by greenfield banks might reflect their better access to international capital markets either directly or via their parent banks. We are able to test this hypothesis by including the share of interbank liabilities with nonresident banks to capture foreign funding (model 3 ). ${ }^{20}$ This additional explanatory variable turns out to be significant and has a positive sign, indicating that banks that have higher share of their funding from nonresident banks are more likely to give loans in foreign currency as well. However, the inclusion of this variable does not change by a lot the magnitude of coefficient of greenfield dummy. Therefore, higher propensity of greenfield banks to extend loans in foreign currency stems not only from their better access to international capital markets, but also other factors, such as currency risk management, or the servicing of different segments of customers.

Among other variables, bank size appears to be significant in the share regressions, which might indicate that larger banks have on average better access to foreign currency liabilities, which they lend on to borrowers. The decrease in the inflation and interest rates made lending in foreign currency less attractive for borrowers, diminishing the growth in these loans on average.

To summarize the results obtained up to this point, we found that foreign banks that enter via greenfield investment lend more to transparent firms (private firms) and less to opaque firms (entrepreneurs), they extend more loans at short-term, and in foreign currency. We also found that there is some convergence between banks in terms of portfolio composition as over time

\footnotetext{
${ }^{20} \mathrm{We}$ can test this hypothesis only for a limited time period, as the data on interbank liabilities is reported only after 2001. We do not present these results in the paper, but they are available upon request.
} 
greenfield banks lend more to opaque and less to transparent borrowers. It is interesting to note, however, that there is not much convergence with respect to currency and maturity of loans between foreign and domestic banks. We find that greenfield banks lend more shortterm and more in foreign currency than domestic private banks, and these differences are not disappearing over time.

\section{EMPIRICAL ANALYSIS-LOAN RATES}

\section{A. Empirical Model}

Next, we look at the determinants of bank lending rates. In particular, we investigate whether there are differences between interest rates charged by banks with different ownership structure after we control for the portfolio composition. Section IV has clearly shown that the portfolio composition is different across bank types. To identify the importance of portfolio composition, we first estimate a baseline lending rate model with specification similar to other studies. We do that to be able to compare our results with the existing literature (Martinez Peria and Mody, 2004; Claeys and Hainz, 2007). In this specification, we use lending rate for all borrowers as a dependent variable and examine the effect of bank ownership and mode of entry on costs of loans for an average borrower, controlling for bank characteristics, macroeconomic environment and market structure.

To be more formal, we estimate the following model:

$L_{i t}=\alpha_{0}+\alpha_{1}$ Ownership $_{i t-1}+\alpha_{2}$ Bank $_{\text {characteristics }}^{i t-1}+\alpha_{3}$ Macro $_{t-1}+$ $+\alpha_{4}$ Market Structure $_{i t-1}+$ Season $_{t}+\varepsilon_{i t}$,

where the variables are as defined before (see Table 1 and 2) except for $L_{i t}$, the lending rate of bank $i$ during quarter $t$, and Market Structure $_{i t}$, which includes variables that control for market concentration and market power (Herfindahl Index and Market Share).

\section{B. Results for the Average Bank Lending Rate}

The results of estimating model (2) where we do not distinguish between the different borrower types are presented in the first column of Table 6 . We find that greenfield banks charge their borrowers 0.9 percent less per quarter (or 3.6 percent on an annual basis), whereas takeover banks do not charge less than domestic banks, which are omitted in our estimations and, thus, serve as a benchmark. Among bank specific variables, the deviation from the median nonperforming loans, costs, and market share are significant and have the expected signs. Banks that have higher costs and face higher credit risk are more likely to charge higher lending rates. Large banks appear to reap economies of scale which they transfer to their customers in the form of lower lending rates. 
In line with the literature that analyzes whether benefits of foreign ownership are constant over time, we split our takeover and greenfield variables separately into dummies that take the value of 1 if a bank was established (for greenfield) or acquired (for takeover) before 2001 and after that date (in line with our share regressions). Our findings (column 2) show that the impact of greenfield mode of foreign entry disappears with time, which is usually interpreted in the literature as convergence between banks of different types of ownership due to competition or changes in portfolio composition. Our results corroborate previous finding in the literature and therefore, our data reflect the situation in developing and transition countries and does not just deal with a particular Polish case (Martinez Peria and Mody, 2004; Claeys and Hainz, 2007). As a robustness check, for all interest rate regressions we also split the greenfield and takeover variables into dummies that take the value of 1 if a bank was established (for greenfield) or acquired (for takeover) less than three years ago and banks that were over three years old. We repeated all estimations. The results are robust to this, and are available upon request.

As mentioned earlier, the disadvantage of the above model is the lack of information on borrower type, which does not allow us to separate the reasons for lower lending rates of greenfield banks, i.e., their superior performance or their portfolio composition targeted to more transparent borrowers. Our first step to remedy this is to include the share of transparent and opaque borrowers in banks' portfolio into our baseline regression. The results, presented in column 3 of Table 6, clearly show that the impact of bank ownership and foreign banks' mode of entry disappears: average lending rates between banks are no longer statistically different. It seems, therefore, that the previous findings suffered from the omitted variable bias, which rendered some of the ownership variables significant. ${ }^{21}$ Our results also hold if we account for the dynamic effects (column 4): we no longer see any evidence of convergence in foreign bank's interest rates. Consequently, our findings present us with an initial proof of the portfolio composition hypothesis.

\section{Results for Borrower Types-Lending Rate}

To further test the portfolio composition hypothesis, we estimate model (2) separately for private firms and entrepreneurs. Since we estimate our models with homogeneous borrowers in each sample, the composition effect is removed from our estimations and we succeed to observe the pure effect of bank ownership and mode of entry on lending rates. As a result, any remaining differences between banks with respect to ownership would serve as evidence

\footnotetext{
${ }^{21}$ Our data set does not include information on the provision of collateral. We believe that this only would reinforce our conclusions regarding the performance hypothesis as theory suggests that foreign banks are more likely to demand for collateral (Sengupta, 2007). For example, if we found that foreign banks charge lower lending rates, the explanation could related either to higher cost-efficiency or to differences in collateral. But since we find no impact, we can more safely reject the performance hypothesis.
} 
for our performance hypothesis. If we do not find such differences, this will be a proof for the portfolio composition hypothesis.

We present our results for transparent borrowers - private firms - in Table 7a, and for opaque ones - entrepreneurs - in Table 7b. Our results (column 1 in both tables) show that, once we control for the portfolio composition effect, the mode of entry of foreign banks is not an important determinant of lending rates. This means that the mode of foreign bank ownership has no impact on lending rates, which contradicts the existing literature on the impact of the mode of foreign bank entry on bank lending rates (Martinez Peria and Mody, 2004; Claeys and Hainz, 2007; de Haas and Lelyveld, 2006). Our different results stem from the fact that previous studies were not able to control for portfolio composition of banks' loan portfolios.

As mentioned above, currency and maturity may also have important impact on interest rates charged by banks. To control for currency denomination of loans, we augment our model with a variable that controls for the share of loans in foreign currency in banks' portfolios (column 2 in Tables 7a and 7b). As expected, higher share of foreign currency loans has a negative impact on average lending rates. However, this fact has only a slight impact on our final results. We still find that foreign bank ownership and mode of entry do not influence lending rates. However, our results indicate that state-owned banks offer lower lending rates once we control for loan currency. Annualized, the difference amounts to 2.8 percent, and is both statistically and economically significant. As shown in the descriptive statistics, stateowned banks extend more loans in domestic currency than foreign banks. Since these loans are on average more expensive than foreign currency loans, the failure to control for this factor makes loans extended by state-owned banks appear to be more expensive as well.

To control for loan maturity we augment our model with variables that capture the share of short-term and long-term loans in banks' portfolios (Tables $7 \mathrm{a}$ and $7 \mathrm{~b}$, column 3). Our results show that maturity is not a significant determinant of lending rates, which is probably due to a complexity of various factors that play in different directions. More importantly however, when we look at the impact of foreign bank ownership and the mode of entry on lending rates after controlling for loan maturity, our results are robust. It is also the case if we control for both currency and maturity simultaneously (Tables $7 \mathrm{a}$ and $7 \mathrm{~b}$, column 4).

\section{Does Time Influence Lending Rates?}

Even though we do not find an impact of foreign bank ownership and mode of entry on banks' lending rates, we would like to analyze whether it is temporary and maybe banks with longer presence in the market are more able to capitalize on their advantages. To do this, we again split our takeover and greenfield variables separately into dummies that take the value of 1 if bank was newly established (for greenfield) or acquired (for takeover) before 2001, and banks that entered (or were acquired) after that date. The results are presented in Tables $8 \mathrm{a}$ and $8 \mathrm{~b}$ for transparent and opaque borrowers, respectively. 
Our findings suggest that time does not play an important role and even after many years of operations lending rates of foreign banks are not different from those of domestic private banks. Our results are very robust to different specifications of variables accounting for time dynamics. To check the stability of our results we use different year in which we split the sample, we use bank age (as mentioned above) or we use interaction variable between age and time and foreign bank dummies assuming a linear relationship. Our results remain the same and we do not find any age or time dynamic effects. These results are not reported in the paper for brevity, but are available upon request.

Our results are contrary to the existing literature, which shows that lending rates of greenfield banks are lower on average but converge with lending rates of other banks in the longer term. We argue that previous findings are due to changing portfolio composition of foreign banks, and not due to convergence in performance. If we look at the descriptive statistics in Section III, we observe that greenfield banks decreased the share of their loans to large private firms, and more recently, they started to extend less loans in foreign currency. Both of these factors should contribute to an increase of average lending rates of greenfield banks over the analyzed period, but this is purely a portfolio composition effect.

\section{FINDINGS FOR DOMESTIC BANKS}

From the perspective of public policy, it is not important if foreign banks prefer to target more transparent clients as long as domestic banks continue to lend to SMEs (Detragiache and others., 2008). However, Dell'Ariccia and Marquez (2004) predict that domestic banks increase the share of opaque clients in the wake of foreign bank entry, but this brings about the deterioration in their overall portfolio quality. To test these hypotheses, we analyze the impact of foreign bank entry on the supply of loans and portfolio quality of domestic banks. To this end, we estimate two models on the sample of domestic banks. First, we analyze the portfolio shares:

$$
\begin{aligned}
& \ln \left(\frac{P_{i t}}{1-P_{i t}}\right)=\delta_{0}+\delta_{1} \text { State }_{i t-1}+\delta_{2}{\text { Share } \text { greenfield }_{t-1}+\delta_{3} \text { Share }_{\text {takeover }}-1} \\
& +\delta_{4} \text { Bank characteristics }_{i t-1}+\delta_{5} \text { Macro }_{t-1}+\text { Season }_{t}+\varepsilon_{i t}
\end{aligned}
$$

Then we look at the nonperforming loans:

$$
\begin{aligned}
& N P L_{i t}=\gamma_{0}+\gamma_{1} \text { State }_{i t-1}+\gamma_{2} \text { Share } \text { greenfield }_{t-1}+\gamma_{3} \text { Share }_{\text {takeover }} \text { Sh }_{t-1} \\
& +\gamma_{4} \text { Macro }_{t-1}+\text { Season }_{t}+\varepsilon_{i t}
\end{aligned}
$$


where in all regressions Share greenfield ${ }_{t}$ is the share of greenfield and Share takeover $_{t}$ is the share of takeover banks in the total banking loans at quarter $\mathrm{t}$, and $N P L_{t}$ is the measure for nonperforming loans, and the other variables are as defined above.

We have seen so far that foreign banks that enter via greenfield investment lend more to large firms and less to entrepreneurs, they extend more loans at short-term, and in foreign currency. However, the entry of foreign banks might influence the supply of loans not only directly via lending by these banks, but also indirectly by influencing the behavior of domestic institutions. For example, higher competition in the market for transparent borrowers might induce domestic banks to lend more to opaque clients. At the same time, if greenfield banks cherry pick the best borrowers, the quality of loan portfolios of domestic banks could deteriorate. To test these hypotheses we include the share of loans granted by greenfield and takeover banks into the share and nonperforming loans regressions, and run them on the sample of domestic banks.

The results presented in Table 9 show that domestic banks increased the share of entrepreneurs in their portfolios in the wake of foreign bank entry. Even though this impact is only significant in the period after 2001 and for the share of loans granted by greenfield banks, it is consistent with theoretical predictions of Dell'Ariccia and Marquez (2004). As a result of greenfield entry, domestic banks appear to refocus their lending more towards opaque clients for whom they have the largest comparative advantages.

In Table 10, we show the impact of foreign bank entry on the level of nonperforming loans of domestic banks. Our results show that foreign banks have an opposite effect on the quality of loan portfolios of domestic banks depending on their mode of entry. The entry of greenfield banks decreased the quality of loan portfolios of domestic banks to both transparent and opaque clients. This is consistent with the hypothesis that greenfield banks attract the best clients forcing domestic banks to lend to higher risk borrowers, which were likely to be turned down by foreign lenders who possess superior screening techniques (Claeys and Hainz, 2007). Among entrepreneurs, greenfield banks might have attracted the relatively more transparent borrowers to whom they could lend relying on transaction-based lending techniques. This deteriorating portfolio quality of domestic banks in the wake of foreign bank entry via greenfield investment is consistent with predictions of Dell'Ariccia and Marquez (2004).

At the same time, the entry of takeover banks appears to decrease the amount of nonperforming loans of domestic banks. This could be attributed to positive spillovers with respect to lending techniques, loan monitoring or risk management. The fact that the observed improvement concerns only loans to private firms suggests that domestic banks lending to entrepreneurs might rely mostly on relationship lending. 


\section{Conclusions}

Using a unique novel data set providing us with detailed information on bank portfolios, we explore how foreign bank entry determines credit allocation in emerging markets. In particular, we investigate the impact of the mode of foreign entry-greenfield and takeover - on banks' portfolio allocation to borrowers with different degrees of informational transparency, as well as by maturities and currencies. The impact of foreign entry on credit allocation may stem from the superior performance of foreign entrants ("performance hypothesis"), or reflect borrower informational capture ("portfolio composition hypothesis"). Our results are broadly in line with the theoretical models underpinning the portfolio composition hypothesis, showing that informational capture determines bank credit allocation (see e.g., Dell'Ariccia and Marquez, 2004, or Sengupta, 2007).

Our main result can be further summarized as follows. First, we show that the mode of entry is a very important determinant of foreign banks' portfolio composition. Greenfield banks devote a higher share of their portfolio to transparent firms and a smaller one to opaque firms than domestic banks, whereas there are no large differences between takeover banks and domestic private banks. We further find that over time greenfield banks shifted away from transparent borrowers towards more opaque ones. This is consistent with theories arguing that greenfield banks have comparative advantages at lending to transparent borrowers using hard information initially, but over time also become privately informed and start servicing opaque borrowers based on soft information.

Second, we argue that the result established in the existing literature indicating that the average lending rate of greenfield banks is lower than that of domestic private banks has to be attributed to a different portfolio composition: greenfield banks offer more loans to transparent borrowers that exhibit a lower cost of credit. When the interest rates offered to different borrower types are analyzed, the effect of foreign ownership disappears.

Third, our results reveal that greenfield banks extend more loans in foreign currency. This reflects their better access to foreign currency funding in international capital markets either directly or via their parent companies, and the fact that they lend more to multinational corporations and exporting firms. Moreover, greenfield banks extend more loans at shorter maturities and less loans at longer maturities, which may reflect their short-term commitment to host economies. Furthermore, we find very little evidence of convergence between greenfield and private banks in terms of loan maturity and currency. The composition of portfolios has remained the same during the analyzed period and greenfield banks consistently lend more at shorter maturities and in foreign currency.

Finally, higher participation of greenfield banks had negative impacts on the loan portfolio quality of domestic banks. Interestingly, the entry of takeover banks had no impact on the loan portfolio of domestic banks for opaque firms, but improved the loan portfolio quality of 
transparent firms. This suggests spillover effects as domestic institutions learn to use transaction-based lending techniques in lending to transparent borrowers.

Our findings have important policy implications in light of the current crisis. On the one hand, the fact that foreign banks have more foreign currency loans in their portfolios renders them more vulnerable to credit risk. As local currencies have depreciated in many emerging economies, it becomes more difficult for borrowers - that do not receive their income in foreign currency - to service their loans. On the other hand, shorter loan maturity of foreign banks' portfolios allows them to diminish credit supply by not extending new loans, which could protect their balances sheets but would impose credit constraints on borrowers. 
Table 1. Definition of Variables

\begin{tabular}{|c|c|}
\hline Variable & Definition \\
\hline State-owned & $\begin{array}{l}\text { A dummy variable which takes the value of one if more than } 50 \text { percent of } \\
\text { the bank is owned by the state, zero otherwise }\end{array}$ \\
\hline Takeover & $\begin{array}{l}\text { A dummy variable which takes the value of one if more than } 50 \text { percent of } \\
\text { the bank is owned by the foreign investor, which entered the market via } \\
\text { acquisition of an existing bank, zero otherwise }\end{array}$ \\
\hline Greenfield & $\begin{array}{l}\text { A dummy variable which takes the value of one if more than } 50 \text { percent of } \\
\text { the bank is owned by the foreign investor, which entered the market via } \\
\text { establishing a new bank, zero otherwise }\end{array}$ \\
\hline Lending rate & $\begin{array}{l}\text { The ratio of interest income to total loans. This variable is calculated for } \\
\text { all borrowers, and for private firms and entrepreneurs separately. } \\
\text { Calculated quarterly, unless explicitly stated otherwise }\end{array}$ \\
\hline NPL & $\begin{array}{l}\text { The ratio of nonperforming loans to total loans. This variable is calculated } \\
\text { for all borrowers and for private firms and entrepreneurs separately. }\end{array}$ \\
\hline Market share & $\begin{array}{l}\text { Share of loans of a bank in the total loans of banking sector in host } \\
\text { country. This variable is calculated for all borrowers, and for private firms } \\
\text { and entrepreneurs separately. }\end{array}$ \\
\hline Capitalization & The ratio of risk adjusted capital \\
\hline Cost & The ratio of personnel and administrative costs to total assets \\
\hline Herfindahl index & $\begin{array}{l}\text { Herfindahl index, calculated as the sum of squared shares of loans. This } \\
\text { variable is calculated for all borrowers and for private firms and } \\
\text { entrepreneurs separately. }\end{array}$ \\
\hline $\begin{array}{l}\text { Share private } \\
\text { (entrepreneur) }\end{array}$ & The ratio of loans to private firms (entrepreneurs) in bank's portfolio. \\
\hline $\begin{array}{l}\text { Share greenfield } \\
\text { (takeover) }\end{array}$ & $\begin{array}{l}\text { The ratio of loans granted by greenfield (takeover) banks to total loans } \\
\text { granted by all banks in quarter } t\end{array}$ \\
\hline FX loans & $\begin{array}{l}\text { The ratio of loans in foreign currency in bank's loan portfolio. This variable } \\
\text { is calculated for all borrowers, and for private firms and entrepreneurs } \\
\text { separately. }\end{array}$ \\
\hline Short-term loans & $\begin{array}{l}\text { The ratio of loans with maturity less than } 1 \text { year in a bank's loan portfolio. } \\
\text { This variable is calculated for all borrowers, and for private firms and } \\
\text { entrepreneurs separately. }\end{array}$ \\
\hline Long-term loans & $\begin{array}{l}\text { The ratio of loans with maturity over } 5 \text { years in a bank's loan portfolio. } \\
\text { This variable is calculated for all borrowers, and for private corporations } \\
\text { and entrepreneurs separately. }\end{array}$ \\
\hline GDP & Real quarterly growth rate of GDP \\
\hline Inflation & Quarterly inflation rate \\
\hline Real interest rate & $\begin{array}{l}\text { Real short-term interest rate, calculated using } 3 \text { month WIBOR (Warsaw } \\
\text { interbank offered rate) interest rate and inflation rate by Fisher equation }\end{array}$ \\
\hline
\end{tabular}


Table 2. Summary Statistics

\begin{tabular}{|c|c|c|c|c|c|}
\hline Variable & Obs & Mean & Std. Dev. & A & B \\
\hline \multicolumn{6}{|l|}{ Share of loans to private firms in portfolios of } \\
\hline greenfield & 750 & 0.667 & 0.348 & $* * *$ & *** \\
\hline takeover & 738 & 0.404 & 0.263 & $* * *$ & \\
\hline private & 563 & 0.329 & 0.225 & & \\
\hline state-owned & 330 & 0.292 & 0.166 & $* * *$ & \\
\hline \multicolumn{6}{|c|}{ Share of loans to entrepreneurs in portfolios of } \\
\hline greenfield & 750 & 0.082 & 0.141 & $* * *$ & $* * *$ \\
\hline takeover & 738 & 0.098 & 0.082 & $* * *$ & \\
\hline private & 563 & 0.151 & 0.120 & & \\
\hline state-owned & 330 & 0.103 & 0.099 & $* * *$ & \\
\hline \multicolumn{6}{|l|}{ Share of loans up to 1 year in portfolios of } \\
\hline greenfield & 750 & 0.537 & 0.327 & $* * *$ & *** \\
\hline takeover & 738 & 0.358 & 0.178 & $* * *$ & \\
\hline private & 563 & 0.411 & 0.214 & & \\
\hline state-owned & 330 & 0.296 & 0.169 & $* * *$ & \\
\hline \multicolumn{6}{|c|}{ Share of loans from 1 to 5 years in portfolios of } \\
\hline greenfield & 750 & 0.306 & 0.283 & $* * *$ & *** \\
\hline takeover & 738 & 0.381 & 0.177 & & \\
\hline private & 563 & 0.374 & 0.177 & & \\
\hline state-owned & 330 & 0.350 & 0.204 & * & \\
\hline \multicolumn{6}{|l|}{ Share of loans over 5 years in portfolios of } \\
\hline greenfield & 750 & 0.157 & 0.179 & $* * *$ & *** \\
\hline takeover & 738 & 0.261 & 0.194 & $* * *$ & \\
\hline private & 563 & 0.215 & 0.203 & & \\
\hline state-owned & 330 & 0.353 & 0.267 & $* * *$ & \\
\hline \multicolumn{6}{|c|}{ Share of loans in foreign currency in portfolios of } \\
\hline greenfield & 750 & 0.302 & 0.235 & $* * *$ & $* * *$ \\
\hline takeover & 738 & 0.216 & 0.208 & $* * *$ & \\
\hline private & 563 & 0.107 & 0.161 & & \\
\hline state-owned & 330 & 0.108 & 0.127 & * & \\
\hline Lending rate & 2073 & 0.174 & 0.126 & & \\
\hline \multicolumn{6}{|l|}{ Lending rates on loans issued by } \\
\hline greenfield & 632 & 0.147 & $0.089 * * *$ & & \\
\hline takeover & 605 & 0.165 & $0.161^{* * *}$ & & \\
\hline state-owned & 307 & 0.174 & $0.086 * * *$ & & \\
\hline private & 529 & 0.217 & 0.126 & & \\
\hline Lending rate on loans to private firms & 2151 & 0.167 & 0.141 & & \\
\hline by greenfield & 618 & 0.152 & $0.138 * * *$ & & \\
\hline by takeover & 600 & 0.155 & $0.153^{* * *}$ & & \\
\hline by state-owned & 307 & 0.161 & $0.085 * * *$ & & \\
\hline by private & 524 & 0.212 & 0.155 & & \\
\hline$د$ Lending rate on loans to entrepreneurs & 1836 & 0.190 & 0.170 & & \\
\hline by greenfield & 329 & 0.145 & $0.199 * * *$ & & \\
\hline by takeover & 598 & 0.173 & $0.152 * * *$ & & \\
\hline by state-owned & 307 & 0.197 & $0.197 * * *$ & & \\
\hline by private & 523 & 0.235 & 0.180 & & \\
\hline Nonperforming loans & 2151 & 0.368 & 1.233 & & \\
\hline
\end{tabular}


Table 2. Summary Statistics (concluded)

\begin{tabular}{|c|c|c|c|c|c|}
\hline Variable & Obs & Mean & Std. Dev. & A & B \\
\hline \multicolumn{6}{|c|}{ Nonperforming loans to private firms by } \\
\hline greenfield & 739 & 0.078 & 1.241 & $* * *$ & $* * *$ \\
\hline takeover & 738 & 0.444 & 1.466 & $* * *$ & \\
\hline private & 563 & 0.808 & 1.746 & & \\
\hline state-owned & 330 & 0.565 & 1.167 & $* *$ & \\
\hline \multicolumn{6}{|c|}{ Nonresident interbank liabilities by } \\
\hline greenfield & 375 & 0.140 & 0.193 & $* * *$ & $* * *$ \\
\hline takeover & 401 & 0.054 & 0.114 & $* * *$ & \\
\hline private & 117 & 0.002 & 0.008 & & \\
\hline state-owned & 107 & 0.016 & 0.032 & $* * *$ & \\
\hline ROA & 2196 & 0.001 & 0.074 & & \\
\hline Cost & 2284 & 0.013 & 0.022 & & \\
\hline Capitalization & 2284 & 0.205 & 0.327 & & \\
\hline Herfindahl index & 2270 & 0.072 & 0.009 & & \\
\hline private firms & 2270 & 0.068 & 0.009 & & \\
\hline entrepreneurs & 2270 & 0.070 & 0.012 & & $* * *$ \\
\hline Market share & 2269 & 0.017 & 0.031 & & \\
\hline GDP growth & 2160 & 0.016 & 0.086 & & \\
\hline Inflation & 2160 & 0.015 & 0.015 & & \\
\hline Real interest rate & 2160 & 0.018 & 0.013 & & \\
\hline
\end{tabular}

***, ${ }^{* *}$, and ${ }^{*}$ correspond to $1 \%, 5 \%$ and $10 \%$ significance levels that the difference: in column A between greenfield, takeover, state-owned and private banks, and in column B between private firms and entrepreneurs is different from zero. 
Table 3. Borrower Type: Share of Loans to Private Firms and Entrepreneurs

\begin{tabular}{|c|c|c|c|c|}
\hline & $\begin{array}{r}\text { Private firms } \\
\text { (transparent) } \\
1\end{array}$ & $\begin{array}{l}\text { Private firms } \\
\text { (transparent) }\end{array}$ & $\begin{array}{l}\text { Entrepreneurs } \\
\begin{array}{l}\text { (opaque) } \\
3\end{array}\end{array}$ & $\begin{array}{l}\text { Entrepreneurs } \\
\text { (opaque) }\end{array}$ \\
\hline Greenfield & $\begin{array}{r}2.286^{* * *} \\
{[0.546]}\end{array}$ & & $\begin{array}{r}-1.143^{* *} \\
{[0.508]}\end{array}$ & \\
\hline Takeover & $\begin{array}{l}-0.108 \\
{[0.529]}\end{array}$ & & $\begin{array}{l}-0.396 \\
{[0.336]}\end{array}$ & \\
\hline State-owned & $\begin{array}{r}-0.454 \\
{[0.374]}\end{array}$ & $\begin{array}{r}-0.492 \\
{[0.380]}\end{array}$ & $\begin{array}{l}-0.188 \\
{[0.335]}\end{array}$ & $\begin{array}{l}-0.223 \\
{[0.331]}\end{array}$ \\
\hline Greenfield* before 2001 & & $\begin{array}{r}2.641^{* * *} \\
{[0.567]}\end{array}$ & & $\begin{array}{r}-2.046^{* * *} \\
{[0.735]}\end{array}$ \\
\hline Greenfield* after 2001 & & $\begin{array}{r}1.906^{* * *} \\
{[0.594]}\end{array}$ & & $\begin{array}{l}-0.756 \\
{[0.505]}\end{array}$ \\
\hline Takeover* before 2001 & & $\begin{array}{r}0.232 \\
{[0.489]}\end{array}$ & & $\begin{array}{l}-0.036 \\
{[0.289]}\end{array}$ \\
\hline Takeover* after 2001 & & $\begin{array}{r}-0.452 \\
{[0.608]}\end{array}$ & & $\begin{array}{l}-0.589 \\
{[0.430]}\end{array}$ \\
\hline ROA & $\begin{array}{r}-21.192^{* * *} \\
{[6.915]}\end{array}$ & $\begin{array}{r}-20.561^{* * *} \\
{[6.859]}\end{array}$ & $\begin{array}{r}-0.373 \\
{[5.578]}\end{array}$ & $\begin{array}{l}-1.001 \\
{[5.336]}\end{array}$ \\
\hline Cost & $\begin{array}{r}-105.978^{\star * \star} \\
{[16.64]}\end{array}$ & $\begin{array}{r}-105.166^{\star \star \star} \\
{[16.463]}\end{array}$ & $\begin{array}{r}0.043 \\
{[17.493]}\end{array}$ & $\begin{array}{r}0.308 \\
{[18.484]}\end{array}$ \\
\hline Capitalization & $\begin{array}{r}1.666^{* * *} \\
{[0.349]}\end{array}$ & $\begin{array}{r}1.644^{* * *} \\
{[0.338]}\end{array}$ & $\begin{array}{r}-1.651 \\
{[1.018]}\end{array}$ & $\begin{array}{r}-1.472 \\
{[1.013]}\end{array}$ \\
\hline Bank size & $\begin{array}{l}0.238^{* *} \\
{[0.115]}\end{array}$ & $\begin{array}{l}0.236^{* *} \\
{[0.118]}\end{array}$ & $\begin{array}{r}-0.255^{* * *} \\
{[0.095]}\end{array}$ & $\begin{array}{r}-0.229^{* *} \\
{[0.094]}\end{array}$ \\
\hline NPL & $\begin{array}{r}-0.237^{* *} \\
{[0.105]}\end{array}$ & $\begin{array}{r}-0.240^{* *} \\
{[0.102]}\end{array}$ & $\begin{array}{r}-0.440^{* * *} \\
{[0.101]}\end{array}$ & $\begin{array}{r}-0.442^{* * *} \\
{[0.103]}\end{array}$ \\
\hline GDP & $\begin{array}{r}1.707 \\
{[1.496]}\end{array}$ & $\begin{array}{r}1.353 \\
{[1.533]}\end{array}$ & $\begin{array}{r}1.903 \\
{[2.099]}\end{array}$ & $\begin{array}{r}2.058 \\
{[2.107]}\end{array}$ \\
\hline Inflation & $\begin{array}{r}29.458^{* * *} \\
{[7.144]}\end{array}$ & $\begin{array}{r}16.877^{* *} \\
{[6.880]}\end{array}$ & $\begin{array}{r}5.559 \\
{[8.509]}\end{array}$ & $\begin{array}{r}7.322 \\
{[6.540]}\end{array}$ \\
\hline Real interest rate & $\begin{array}{r}23.402^{* * *} \\
{[6.612]}\end{array}$ & $\begin{array}{r}17.266^{* * *} \\
{[6.171]}\end{array}$ & $\begin{array}{r}7.734 \\
{[7.142]}\end{array}$ & $\begin{array}{r}9.652 \\
{[6.408]}\end{array}$ \\
\hline $\begin{array}{l}\text { Observations } \\
\text { Number of banks }\end{array}$ & $\begin{array}{r}2133 \\
107\end{array}$ & $\begin{array}{r}2133 \\
107\end{array}$ & $\begin{array}{r}1802 \\
101\end{array}$ & $\begin{array}{r}1802 \\
101\end{array}$ \\
\hline R-squared & 0.365 & 0.372 & 0.199 & 0.226 \\
\hline
\end{tabular}

Table 3 presents the results of equation (1). The dependent variable is the log-odds ratio of the share of loans to private firms and entrepreneurs in banks' portfolios. The table lists coefficients and standard errors (in parentheses) from regression with pooled OLS with robust standard errors clustered on banks. All dependent variables except for ownership dummies are lagged by one quarter. Regressions include seasonal dummies. Definitions of variables are provided in Table 1. , , and " correspond to $1 \%, 5 \%$ and $10 \%$ significance levels, respectively. 
Table 4. Loan Maturity: Share of Loans by Maturity in Banks' Portfolios

\begin{tabular}{|c|c|c|c|c|}
\hline & $\begin{array}{r}\text { Up } 1 \text { year } \\
1\end{array}$ & $\begin{array}{r}\text { Up } 1 \text { year } \\
2\end{array}$ & $\begin{array}{r}\text { Over } 5 \text { years } \\
3\end{array}$ & $\begin{array}{r}\text { Over } 5 \text { years } \\
4\end{array}$ \\
\hline Greenfield & $\begin{array}{l}1.030^{\star *} \\
{[0.397]}\end{array}$ & & $\begin{array}{r}-1.043^{\star *} \\
{[0.400]}\end{array}$ & \\
\hline Takeover & $\begin{array}{r}0.022 \\
{[0.223]}\end{array}$ & & $\begin{array}{r}-0.721 \\
{[0.458]}\end{array}$ & \\
\hline State-owned & $\begin{array}{r}-0.729^{* *} \\
{[0.335]}\end{array}$ & $\begin{array}{r}-0.728^{* *} \\
{[0.336]}\end{array}$ & $\begin{array}{r}0.196 \\
{[0.449]}\end{array}$ & $\begin{array}{r}0.170 \\
{[0.447]}\end{array}$ \\
\hline Greenfield* before 2001 & & $\begin{array}{r}1.168^{* * *} \\
{[0.438]}\end{array}$ & & $\begin{array}{r}-1.240^{* *} \\
{[0.482]}\end{array}$ \\
\hline Greenfield* after 2001 & & $\begin{array}{l}0.924^{* *} \\
{[0.402]}\end{array}$ & & $\begin{array}{r}-0.964^{* *} \\
{[0.414]}\end{array}$ \\
\hline Takeover* before 2001 & & $\begin{array}{r}0.003 \\
{[0.257]}\end{array}$ & & $\begin{array}{l}-0.403 \\
{[0.368]}\end{array}$ \\
\hline Takeover* after 2001 & & $\begin{array}{r}0.005 \\
{[0.228]}\end{array}$ & & $\begin{array}{l}-0.921 \\
{[0.558]}\end{array}$ \\
\hline ROA & $\begin{array}{r}-6.286^{* *} \\
{[2.525]}\end{array}$ & $\begin{array}{r}-6.205^{\star *} \\
{[2.504]}\end{array}$ & $\begin{array}{l}-7.517 \\
{[7.223]}\end{array}$ & $\begin{array}{l}-7.274 \\
{[7.037]}\end{array}$ \\
\hline Cost & $\begin{array}{l}-15.891 \\
{[11.495]}\end{array}$ & $\begin{array}{l}-16.154 \\
{[11.528]}\end{array}$ & $\begin{array}{l}-30.477 \\
{[21.138]}\end{array}$ & $\begin{array}{l}-28.807 \\
{[21.657]}\end{array}$ \\
\hline Capitalization & $\begin{array}{r}0.061 \\
{[0.275]}\end{array}$ & $\begin{array}{r}0.052 \\
{[0.279]}\end{array}$ & $\begin{array}{l}1.448^{\star *} \\
{[0.553]}\end{array}$ & $\begin{array}{l}1.464^{\star *} \\
{[0.579]}\end{array}$ \\
\hline Bank size & $\begin{array}{l}0.120^{*} \\
{[0.067]}\end{array}$ & $\begin{array}{l}0.114^{*} \\
{[0.067]}\end{array}$ & $\begin{array}{r}0.441^{* * *} \\
{[0.135]}\end{array}$ & $\begin{array}{r}0.457^{* * *} \\
{[0.141]}\end{array}$ \\
\hline NPL & $\begin{array}{c}0.182^{*} \\
{[0.094]}\end{array}$ & $\begin{array}{l}0.180^{*} \\
{[0.093]}\end{array}$ & $\begin{array}{r}-0.05 \\
{[0.101]}\end{array}$ & $\begin{array}{l}-0.045 \\
{[0.102]}\end{array}$ \\
\hline GDP & $\begin{array}{r}1.73 \\
{[1.299]}\end{array}$ & $\begin{array}{r}1.618 \\
{[1.316]}\end{array}$ & $\begin{array}{r}-2.596 \\
{[2.003]}\end{array}$ & $\begin{array}{r}-2.52 \\
{[2.043]}\end{array}$ \\
\hline Inflation & $\begin{array}{r}29.968^{* * \star} \\
{[4.393]}\end{array}$ & $\begin{array}{r}27.745^{\star * *} \\
{[4.221]}\end{array}$ & $\begin{array}{r}-13.767^{*} \\
{[8.235]}\end{array}$ & $\begin{array}{r}-15.800^{* *} \\
{[7.097]}\end{array}$ \\
\hline Real interest rate & $\begin{array}{r}27.045^{* * *} \\
{[4.786]}\end{array}$ & $\begin{array}{r}25.739^{* * * *} \\
{[4.362]}\end{array}$ & $\begin{array}{r}-12.552 \\
{[8.087]}\end{array}$ & $\begin{array}{r}-12.778^{*} \\
{[7.418]}\end{array}$ \\
\hline $\begin{array}{l}\text { Observations } \\
\text { Number of banks }\end{array}$ & $\begin{array}{r}2155 \\
108\end{array}$ & $\begin{array}{r}2155 \\
108\end{array}$ & $\begin{array}{r}2024 \\
108\end{array}$ & $\begin{array}{r}2024 \\
108\end{array}$ \\
\hline R-squared & 0.213 & 0.214 & 0.229 & 0.235 \\
\hline
\end{tabular}

Table 4 presents the results of equation (1). The dependent variable is the log-odds ratio of the share of loans with maturity up to 1 year (models 1 and 2) and over 5 years (models 3 and 4) in banks' portfolios. The table lists coefficients and standard errors (in parentheses) from regression with pooled OLS with robust standard errors clustered on banks. All dependent variables except for ownership dummies are lagged by one quarter. Regressions include seasonal dummies. Definitions of variables are provided in Table 1. ${ }^{* *},{ }^{* *}$, and ${ }^{*}$ correspond to $1 \%, 5 \%$ and $10 \%$ significance levels, respectively. 
Table 5. Foreign Currency: Share of Loan Portfolio in Foreign Currency

\begin{tabular}{|c|c|c|c|}
\hline & 1 & 2 & 3 \\
\hline \multirow[t]{2}{*}{ Greenfield } & $1.840^{* * *}$ & & $1.689^{* * *}$ \\
\hline & [0.497] & & [0.481] \\
\hline \multirow[t]{2}{*}{ Takeover } & 0.354 & & 0.307 \\
\hline & [0.579] & & [0.573] \\
\hline \multirow[t]{2}{*}{ State-owned } & -0.425 & -0.413 & -0.463 \\
\hline & [0.512] & {$[0.510]$} & [0.503] \\
\hline \multirow[t]{2}{*}{ Greenfield* before 2001} & & $1.997^{* * *}$ & \\
\hline & & [0.482] & \\
\hline \multirow[t]{2}{*}{ Greenfield* after 2001} & & $1.739^{* * *}$ & \\
\hline & & {$[0.558]$} & \\
\hline \multirow[t]{2}{*}{ Takeover* before 2001} & & 0.220 & \\
\hline & & [0.650] & \\
\hline \multirow[t]{2}{*}{ Takeover* after 2001} & & 0.410 & \\
\hline & & [0.618] & \\
\hline \multirow[t]{2}{*}{ ROA } & -13.463 & -13.582 & -12.168 \\
\hline & {$[10.570]$} & {$[10.575]$} & [10.244] \\
\hline \multirow[t]{2}{*}{ Cost } & -30.016 & -30.901 & -25.788 \\
\hline & [30.239] & {$[29.790]$} & [30.089] \\
\hline \multirow[t]{2}{*}{ Capitalization } & $0.999^{*}$ & $0.987^{*}$ & $1.055^{*}$ \\
\hline & [0.594] & [0.585] & [0.608] \\
\hline \multirow[t]{2}{*}{ Bank size } & $0.378^{* * *}$ & $0.369^{* * *}$ & $0.397^{* * *}$ \\
\hline & [0.110] & [0.109] & [0.110] \\
\hline \multirow[t]{2}{*}{ NPL } & $-0.121^{*}$ & $-0.124^{*}$ & $-0.114^{*}$ \\
\hline & [0.068] & {$[0.068]$} & {$[0.066]$} \\
\hline \multirow[t]{2}{*}{ Interbank liabilities } & & & $1.926^{* * *}$ \\
\hline & & & [0.669] \\
\hline \multirow[t]{2}{*}{ GDP } & 0.334 & 0.144 & 0.085 \\
\hline & [1.866] & {$[1.855]$} & [1.875] \\
\hline \multirow[t]{2}{*}{ Inflation } & 9.832 & 8.933 & 13.752 \\
\hline & [9.098] & [10.109] & [9.492] \\
\hline \multirow[t]{2}{*}{ Real interest rate } & 14.099 & 13.097 & $18.912^{*}$ \\
\hline & [10.227] & [10.641] & [10.726] \\
\hline Observations & 1662 & 1662 & 1662 \\
\hline Number of banks & 92 & 92 & 92 \\
\hline R-squared & 0.223 & 0.225 & 0.234 \\
\hline
\end{tabular}

Table 5 presents the results of equation (1). The dependent variable is the log-odds ratio of the share of loans in foreign currency in banks' portfolios. The table lists coefficients and standard errors (in parentheses) from regression with pooled OLS (robust standard errors clustered on banks). All dependent variables except for ownership dummies are lagged by one guarter. Regressions include seasonal dummies. Definitions of variables are provided in Table 1. ${ }^{* *}$, , and " correspond to $1 \%, 5 \%$ and $10 \%$ significance levels, respectively. 
Table 6. Average Bank Lending Rate

\begin{tabular}{|c|c|c|c|c|}
\hline & 1 & 2 & 3 & 4 \\
\hline \multirow[t]{2}{*}{ Greenfield } & $-0.009^{* *}$ & & 0.003 & \\
\hline & {$[0.004$} & & {$[0.005]$} & \\
\hline \multirow[t]{2}{*}{ Takeover } & 0.002 & & 0.005 & \\
\hline & [0.005] & & [0.005] & \\
\hline \multirow[t]{2}{*}{ State-owned } & -0.002 & -0.001 & -0.004 & -0.004 \\
\hline & {$[0.005]$} & {$[0.005]$} & [0.005] & {$[0.005]$} \\
\hline \multirow[t]{2}{*}{ Takeover* before 2001} & & 0.001 & & 0.002 \\
\hline & & {$[0.004]$} & & [0.004] \\
\hline \multirow[t]{2}{*}{ Takeover* after 2001} & & 0.004 & & 0.006 \\
\hline & & {$[0.007]$} & & {$[0.006]$} \\
\hline \multirow[t]{2}{*}{ Greenfield* before 2001} & & $-0.010^{\star *}$ & & 0.003 \\
\hline & & [0.004] & & {$[0.005]$} \\
\hline \multirow[t]{2}{*}{ Greenfield* after 2001} & & -0.007 & & 0.003 \\
\hline & & [0.005] & & [0.005] \\
\hline \multirow[t]{2}{*}{ Share private } & & & $-0.036^{* * *}$ & $-0.036^{* * *}$ \\
\hline & & & [0.012] & {$[0.012]$} \\
\hline \multirow[t]{2}{*}{ Share entrepreneur } & & & -0.011 & -0.01 \\
\hline & & & [0.009] & [0.009] \\
\hline \multirow[t]{2}{*}{ Capitalization } & 0.006 & 0.006 & 0.01 & 0.01 \\
\hline & {$[0.012]$} & [0.012] & {$[0.012]$} & {$[0.012]$} \\
\hline \multirow[t]{2}{*}{ Cost } & $0.470^{* * *}$ & $0.469^{* * *}$ & 0.087 & 0.085 \\
\hline & [0.093] & [0.093] & {$[0.130]$} & {$[0.131]$} \\
\hline \multirow[t]{2}{*}{ NPL } & $0.010^{* *}$ & $0.010^{* *}$ & $0.011^{* *}$ & $0.011^{* *}$ \\
\hline & {$[0.005]$} & {$[0.005]$} & {$[0.005]$} & {$[0.005]$} \\
\hline \multirow[t]{2}{*}{ Market share } & $-0.114^{* *}$ & $-0.116^{\star \star}$ & $-0.106^{* *}$ & $-0.109^{* *}$ \\
\hline & [0.048] & [0.052] & [0.041] & [0.044] \\
\hline \multirow[t]{2}{*}{ Herfindahl index } & $0.228^{* *}$ & $0.189^{*}$ & $0.225^{* *}$ & $0.212^{\star *}$ \\
\hline & {$[0.087]$} & {$[0.097]$} & {$[0.087]$} & [0.092] \\
\hline \multirow[t]{2}{*}{ GDP } & -0.016 & -0.013 & 0.008 & 0.009 \\
\hline & [0.016] & {$[0.017]$} & [0.018] & [0.018] \\
\hline \multirow[t]{2}{*}{ Inflation } & $0.663^{* * *}$ & $0.718^{* * *}$ & $0.705^{* * *}$ & $0.728^{* * *}$ \\
\hline & [0.101] & [0.092] & [0.083] & {$[0.084]$} \\
\hline \multirow[t]{2}{*}{ Real interest rate } & $0.641^{* * *}$ & $0.664^{* * *}$ & $0.719^{* * *}$ & $0.725^{* * *}$ \\
\hline & [0.126] & [0.121] & [0.098] & [0.101] \\
\hline Observations & 2271 & 2271 & 2271 & 2271 \\
\hline Number of banks & 106 & 106 & 106 & 106 \\
\hline R-squared & 0.323 & 0.325 & 0.399 & 0.399 \\
\hline
\end{tabular}

Table 6 presents the results of equation (2). The dependent variable is the bank-specific average lending rate. The table lists coefficients and standard errors (in parentheses) from regression with pooled OLS with robust standard errors clustered on banks. All dependent variables except for ownership dummies are lagged by one quarter. Regressions include seasonal dummies. Definitions of variables are provided in Table 1. ${ }^{\star \star \star}$, , , and " correspond to $1 \%, 5 \%$ and $10 \%$ significance levels, respectively. 
Table 7a. Loan Rates to Private Firms

\begin{tabular}{|c|c|c|c|c|}
\hline & 1 & 2 & 3 & 4 \\
\hline \multirow[t]{2}{*}{ Greenfield } & -0.001 & 0.005 & -0.001 & 0.004 \\
\hline & [0.005] & [0.004] & [0.005] & [0.005] \\
\hline \multirow[t]{2}{*}{ Takeover } & 0.004 & 0.005 & 0.003 & 0.005 \\
\hline & [0.005] & [0.004] & [0.004] & [0.004] \\
\hline \multirow[t]{2}{*}{ State-owned } & -0.006 & $-0.007^{*}$ & -0.004 & $-0.006^{* *}$ \\
\hline & [0.004] & [0.004] & {$[0.003]$} & {$[0.003]$} \\
\hline \multirow[t]{2}{*}{ FX loans } & & $-0.036^{* * *}$ & & $-0.035^{* * *}$ \\
\hline & & {$[0.006]$} & & {$[0.006]$} \\
\hline \multirow[t]{2}{*}{ Short-term loans } & & & -0.006 & -0.004 \\
\hline & & & {$[0.010]$} & [0.008] \\
\hline \multirow[t]{2}{*}{ Long-term loans } & & & -0.017 & -0.010 \\
\hline & & & [0.012] & [0.010] \\
\hline \multirow{2}{*}{ Capitalization } & $-0.008^{* *}$ & -0.004 & $-0.006^{*}$ & -0.004 \\
\hline & [0.004] & [0.003] & [0.003] & [0.003] \\
\hline \multirow[t]{2}{*}{ Cost } & $0.454^{* *}$ & $0.260^{*}$ & $0.372^{* *}$ & $0.240^{*}$ \\
\hline & [0.183] & [0.143] & [0.158] & [0.144] \\
\hline \multirow[t]{2}{*}{ NPL } & $0.007^{* * *}$ & $0.007^{* * *}$ & $0.007^{* * *}$ & $0.007^{* * *}$ \\
\hline & [0.001] & [0.001] & [0.001] & {$[0.001]$} \\
\hline \multirow[t]{2}{*}{ Market share } & $-0.169^{* * *}$ & $-0.083^{* * *}$ & $-0.130^{* * *}$ & $-0.068^{* *}$ \\
\hline & [0.040] & [0.023] & [0.043] & {$[0.030]$} \\
\hline \multirow[t]{2}{*}{ Herfindahl index } & $0.287^{* * *}$ & $0.258^{* * *}$ & $0.254^{* * *}$ & $0.251^{* * *}$ \\
\hline & [0.095] & [0.087] & [0.086] & [0.086] \\
\hline \multirow[t]{2}{*}{ GDP } & -0.042 & -0.034 & -0.043 & -0.033 \\
\hline & {$[0.030]$} & [0.029] & {$[0.030]$} & [0.029] \\
\hline \multirow[t]{2}{*}{ Inflation } & $0.646^{* * *}$ & $0.697^{* * *}$ & $0.628^{* * *}$ & $0.675^{* * *}$ \\
\hline & [0.088] & [0.072] & [0.088] & [0.083] \\
\hline \multirow[t]{2}{*}{ Real interest rate } & $0.781^{* * *}$ & $0.885^{\star * *}$ & $0.780^{* * *}$ & $0.868^{* * *}$ \\
\hline & [0.004] & [0.005] & [0.003] & {$[0.005]$} \\
\hline Observations & 2239 & 2233 & 2233 & 2233 \\
\hline Number of banks & 104 & 104 & 104 & 104 \\
\hline R-squared & 0.267 & 0.313 & 0.284 & 0.315 \\
\hline
\end{tabular}

Table 7a presents the results of equation (2). The dependent variable is the bank-specific interest rate on loans to private firms (i.e., transparent). The table lists coefficients and standard errors (in parentheses) from regression with pooled OLS with robust standard errors clustered on banks. Herfindahl Index, Market Share, FX loans, Short-term loans and Longterm loans are calculated for private firms. All dependent variables except for ownership dummies are lagged by one quarter. Regressions include seasonal dummies. Definitions of variables are provided in Table $1 .{ }^{* * *}$,, and ${ }^{*}$ correspond to $1 \%, 5 \%$ and $10 \%$ significance levels, respectively. 
Table 7b. Loan Rates to Entrepreneurs

\begin{tabular}{|c|c|c|c|c|}
\hline & 1 & 2 & 3 & 4 \\
\hline \multirow[t]{2}{*}{ Greenfield } & -0.005 & 0.001 & -0.004 & 0.001 \\
\hline & {$[0.007]$} & {$[0.006]$} & {$[0.007]$} & {$[0.006]$} \\
\hline \multirow[t]{2}{*}{ Takeover } & -0.001 & -0.001 & -0.002 & 0.001 \\
\hline & {$[0.006]$} & {$[0.006]$} & {$[0.006]$} & [0.005] \\
\hline \multirow[t]{2}{*}{ State-owned } & -0.004 & -0.004 & -0.004 & -0.004 \\
\hline & [0.006] & [0.005] & [0.005] & [0.005] \\
\hline \multirow[t]{2}{*}{ FX loans } & & $-0.031^{* * *}$ & & $-0.031^{* * *}$ \\
\hline & & [0.007] & & {$[0.007]$} \\
\hline \multirow[t]{2}{*}{ Short-term loans } & & & 0.001 & 0.001 \\
\hline & & & {$[0.007]$} & {$[0.007]$} \\
\hline \multirow[t]{2}{*}{ Long-term loans } & & & 0.001 & 0.007 \\
\hline & & & {$[0.017]$} & [0.017] \\
\hline \multirow[t]{2}{*}{ Capitalization } & 0.013 & {$[0.015$} & 0.016 & 0.015 \\
\hline & {$[0.017]$} & $0.018]$ & {$[0.017]$} & {$[0.017]$} \\
\hline \multirow[t]{2}{*}{ Cost } & 0.533 & {$[0.450$} & 0.561 & 0.459 \\
\hline & [0.331] & $0.329]$ & [0.349] & [0.332] \\
\hline \multirow[t]{2}{*}{ NPL } & $0.009^{* * *}$ & $0.009^{* * *}$ & $0.009^{* * *}$ & $0.009^{* * *}$ \\
\hline & [0.002] & [0.002] & [0.002] & {$[0.002]$} \\
\hline \multirow[t]{2}{*}{ Market share } & $-0.115^{\star * *}$ & $-0.083^{* * *}$ & $-0.107^{* * *}$ & $-0.085^{* * *}$ \\
\hline & {$[0.036]$} & {$[0.026]$} & {$[0.036]$} & [0.028] \\
\hline \multirow[t]{2}{*}{ Herfindahl index } & 0.137 & $0.158^{*}$ & $0.162^{*}$ & $0.162^{*}$ \\
\hline & [0.095] & [0.095] & [0.095] & [0.094] \\
\hline \multirow[t]{2}{*}{ GDP } & $-0.099^{* *}$ & $-0.092^{* *}$ & $-0.103^{* * *}$ & $-0.092^{* *}$ \\
\hline & [0.038] & [0.038] & [0.039] & {$[0.038]$} \\
\hline \multirow[t]{2}{*}{ Inflation } & $0.617^{* * *}$ & $0.586^{* * *}$ & $0.629^{* * *}$ & $0.605^{* * *}$ \\
\hline & [0.127] & [0.123] & {$[0.128]$} & {$[0.120]$} \\
\hline \multirow[t]{2}{*}{ Real interest rate } & $0.529^{* * *}$ & $0.540^{* * *}$ & $0.540^{* * *}$ & $0.558^{* * *}$ \\
\hline & [0.174] & [0.174] & {$[0.172]$} & {$[0.168]$} \\
\hline Observations & 1924 & 1924 & 1924 & 1924 \\
\hline Number of banks & 98 & 98 & 98 & 98 \\
\hline R-squared & 0.189 & 0.219 & 0.196 & 0.219 \\
\hline
\end{tabular}

Table $7 \mathrm{~b}$ presents the results of equation (2). The dependent variable is the bank-specific interest rate on loans to entrepreneurs (i.e., opaque). The table lists coefficients and standard errors (in parentheses) from regression with pooled OLS with robust standard errors clustered on banks. Herfindahl Index, Market Share, FX loans, Short-term loans and Long-term loans are calculated for entrepreneurs. All dependent variables except for ownership dummies are lagged by one quarter. Regressions include seasonal dummies. Definitions of variables are provided in Table $1 . .^{* * *},{ }^{* *}$, and correspond to $1 \%, 5 \%$ and $10 \%$ significance levels, respectively. 
Table 8a. Loan Rates to Private Firms (with time effects)

\begin{tabular}{|c|c|c|c|c|}
\hline & 1 & 2 & 3 & 4 \\
\hline \multirow[t]{2}{*}{ Greenfield* before 2001} & -0.001 & 0.006 & -0.002 & 0.005 \\
\hline & [0.005] & [0.005] & [0.005] & [0.005] \\
\hline \multirow[t]{2}{*}{ 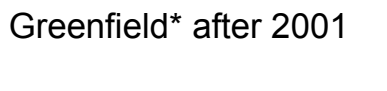 } & -0.001 & 0.004 & 0.001 & 0.003 \\
\hline & {$[0.006]$} & {$[0.005]$} & {$[0.006]$} & [0.006] \\
\hline \multirow[t]{2}{*}{ Takeover* before 2001} & 0.004 & 0.006 & 0.002 & 0.005 \\
\hline & [0.004] & [0.004] & [0.004] & [0.004] \\
\hline \multirow[t]{2}{*}{ Takeover* after 2001} & 0.004 & 0.005 & 0.002 & 0.004 \\
\hline & {$[0.007]$} & [0.006] & {$[0.007]$} & {$[0.006]$} \\
\hline \multirow[t]{2}{*}{ State-owned } & -0.006 & $-0.007^{*}$ & -0.004 & $-0.007^{*}$ \\
\hline & [0.004] & {$[0.004]$} & {$[0.003]$} & [0.003] \\
\hline \multirow[t]{2}{*}{ FX loans } & & $-0.036^{* * *}$ & & $-0.035^{* * *}$ \\
\hline & & [0.006] & & [0.006] \\
\hline \multirow[t]{2}{*}{ Short-term loans } & & & -0.005 & -0.004 \\
\hline & & & {$[0.010]$} & [0.008] \\
\hline \multirow{2}{*}{ Long-term loans } & & & -0.017 & -0.010 \\
\hline & & & [0.013] & [0.010] \\
\hline \multirow[t]{2}{*}{ Cost } & $0.453^{* *}$ & $0.261^{*}$ & $0.373^{* *}$ & $0.241^{*}$ \\
\hline & {$[0.186]$} & [0.144] & {$[0.160]$} & [0.145] \\
\hline \multirow[t]{2}{*}{ Capitalization } & $-0.008^{* *}$ & -0.005 & $-0.006^{*}$ & -0.004 \\
\hline & [0.004] & {$[0.003]$} & [0.003] & [0.003] \\
\hline \multirow[t]{2}{*}{ NPL } & $0.007^{* * *}$ & $0.007^{* * *}$ & $0.007^{* * *}$ & $0.007^{* * *}$ \\
\hline & [0.001] & [0.001] & [0.001] & {$[0.001]$} \\
\hline \multirow[t]{2}{*}{ Market share } & $-0.169^{* * *}$ & $-0.082^{* * *}$ & $-0.128^{* * *}$ & $-0.066^{* *}$ \\
\hline & [0.044] & [0.025] & [0.045] & {$[0.033]$} \\
\hline \multirow[t]{2}{*}{ Herfindahl index } & $0.279^{* *}$ & $0.274^{\star *}$ & $0.258^{* *}$ & $0.276^{\star *}$ \\
\hline & 0.129 & 0.112 & [0.113] & [0.111] \\
\hline \multirow[t]{2}{*}{ GDP } & -0.042 & -0.034 & -0.043 & -0.033 \\
\hline & {$[0.030]$} & {$[0.030]$} & {$[0.030]$} & [0.029] \\
\hline \multirow[t]{2}{*}{ Inflation } & $0.654^{* * *}$ & $0.679^{* * *}$ & $0.625^{\star * *}$ & $0.647^{* * *}$ \\
\hline & [0.139] & {$[0.115]$} & {$[0.137]$} & [0.133] \\
\hline \multirow[t]{2}{*}{ Real interest rate } & $0.784^{* * *}$ & $0.878^{\star * *}$ & $0.780^{* * *}$ & $0.856^{* * *}$ \\
\hline & [0.096] & [0.088] & [0.102] & [0.098] \\
\hline Observations & 2239 & 2233 & 2233 & 2233 \\
\hline Number of banks & 104 & 104 & 104 & 104 \\
\hline R-squared & 0.267 & 0.314 & 0.285 & 0.315 \\
\hline
\end{tabular}

Table 8 a presents the results of equation (2). The dependent variable is the bank-specific interest rate on loans to private firms (i.e., transparent). The table lists coefficients and standard errors (in parentheses) from regression with pooled OLS with robust standard errors clustered on banks. Herfindahl Index, Market Share, FX loans, Short-term loans and Longterm loans are calculated for private firms. All dependent variables except for ownership dummies are lagged by one quarter. Regressions include seasonal dummies. Definitions of variables are provided in Table $1 .{ }^{* \star *}$, , and ${ }^{*}$ correspond to $1 \%, 5 \%$ and $10 \%$ significance levels, respectively. 
Table 8b. Loan Rates to Entrepreneurs (with time effects)

\begin{tabular}{|c|c|c|c|c|}
\hline & 1 & 2 & 3 & 4 \\
\hline \multirow[t]{2}{*}{ Greenfield* before 2001} & -0.006 & 0.001 & -0.006 & 0.001 \\
\hline & [0.005] & {$[0.006]$} & [0.005] & [0.005] \\
\hline \multirow{2}{*}{ Greenfield* after 2001} & -0.004 & 0.002 & -0.002 & 0.001 \\
\hline & {$[0.009]$} & {$[0.008]$} & [0.009] & [0.008] \\
\hline \multirow[t]{2}{*}{ Takeover* before 2001} & -0.002 & -0.001 & -0.002 & 0.001 \\
\hline & [0.005] & [0.004] & [0.005] & [0.004] \\
\hline \multirow[t]{2}{*}{ Takeover* after 2001} & 0.001 & 0.001 & -0.001 & 0.002 \\
\hline & {$[0.008]$} & {$[0.007]$} & {$[0.008]$} & [0.007] \\
\hline \multirow[t]{2}{*}{ State-owned } & -0.004 & -0.004 & -0.004 & -0.004 \\
\hline & {$[0.006]$} & [0.005] & {$[0.006]$} & [0.005] \\
\hline \multirow[t]{2}{*}{ FX loans } & & $-0.031^{* * *}$ & & $-0.031^{* * *}$ \\
\hline & & [0.007] & & [0.007] \\
\hline \multirow[t]{2}{*}{ Short-term loans } & & & 0.001 & 0.001 \\
\hline & & & {$[0.007]$} & [0.007] \\
\hline \multirow[t]{2}{*}{ Long-term loans } & & & 0.001 & 0.007 \\
\hline & & & {$[0.017]$} & {$[0.017]$} \\
\hline \multirow[t]{2}{*}{ Cost } & 0.532 & 0.449 & 0.561 & 0.458 \\
\hline & [0.333] & [0.330] & [0.352] & [0.333] \\
\hline \multirow[t]{2}{*}{ Capitalization } & 0.013 & 0.015 & 0.016 & 0.015 \\
\hline & {$[0.017]$} & {$[0.018]$} & {$[0.017]$} & [0.017] \\
\hline \multirow[t]{2}{*}{ NPL } & $0.009^{* * *}$ & $0.009^{* * *}$ & $0.009^{* * *}$ & $0.009^{* * *}$ \\
\hline & [0.002] & [0.002] & [0.002] & [0.002] \\
\hline \multirow[t]{2}{*}{ Market share } & $-0.116^{* * \star}$ & $-0.084^{* * *}$ & $-0.108^{* * *}$ & $-0.086^{* * *}$ \\
\hline & {$[0.037]$} & {$[0.026]$} & {$[0.037]$} & {$[0.029]$} \\
\hline \multirow[t]{2}{*}{ Herfindahl index } & 0.136 & $0.158^{*}$ & $0.160^{*}$ & $0.161^{*}$ \\
\hline & [0.094] & [0.094] & [0.094] & [0.093] \\
\hline \multirow[t]{2}{*}{ GDP } & $-0.097^{* *}$ & $-0.091^{* *}$ & $-0.102^{* *}$ & $-0.091^{* *}$ \\
\hline & {$[0.040]$} & {$[0.040]$} & [0.041] & [0.040] \\
\hline \multirow[t]{2}{*}{ Inflation } & $0.644^{* * *}$ & $0.603^{* * *}$ & $0.660 * * *$ & $0.623^{\star * *}$ \\
\hline & {$[0.172]$} & [0.166] & [0.167] & {$[0.160]$} \\
\hline \multirow[t]{2}{*}{ Real interest rate } & $0.541^{* * *}$ & $0.547^{* * *}$ & $0.555^{* * *}$ & $0.566^{* \star *}$ \\
\hline & [0.199] & [0.197] & [0.195] & [0.190] \\
\hline Observations & 1924 & 1903 & 1903 & 1903 \\
\hline Number of banks & 98 & 98 & 98 & 98 \\
\hline R-squared & 0.189 & 0.219 & 0.196 & 0.219 \\
\hline
\end{tabular}

Table 8a presents the results of equation (2). The dependent variable is the bank-specific interest rate on loans to entrepreneurs (i.e., opaque). The table lists coefficients and standard errors (in parentheses) from regression with pooled OLS with robust standard errors clustered on banks. Herfindahl Index, Market Share, FX loans, Short-term loans and Long-term loans are calculated for entrepreneurs. All dependent variables except for ownership dummies are lagged by one quarter. Regressions include seasonal dummies. Definitions of variables are provided in Table $1 .{ }^{* * *}$, ${ }^{* *}$, and correspond to $1 \%, 5 \%$ and $10 \%$ significance levels, respectively. 
Table 9. Domestic Banks: Share of Loans to Private Firms and Entrepreneurs

\begin{tabular}{|c|c|c|c|c|}
\hline & $\begin{array}{c}\text { Private } \\
\text { (transparent) } \\
1\end{array}$ & $\begin{array}{c}\text { Private } \\
\text { (transparent) }\end{array}$ & $\begin{array}{l}\text { Entrepreneurs } \\
\begin{array}{c}\text { (opaque) } \\
3\end{array}\end{array}$ & $\begin{array}{l}\text { Entrepreneurs } \\
\begin{array}{c}\text { (opaque) } \\
\end{array}\end{array}$ \\
\hline State-owned & $\begin{array}{r}-0.022 \\
{[0.399]}\end{array}$ & $\begin{array}{r}-0.017 \\
{[0.401]}\end{array}$ & $\begin{array}{r}-0.13 \\
{[0.349]}\end{array}$ & $\begin{array}{l}-0.127 \\
{[0.349]}\end{array}$ \\
\hline $\begin{array}{l}\text { Share greenfield (in this } \\
\text { segment) }\end{array}$ & $\begin{array}{l}-1.502 \\
{[4.375]}\end{array}$ & & $\begin{array}{l}7.787^{* *} \\
{[3.124]}\end{array}$ & \\
\hline $\begin{array}{l}\text { Share takeover (in this } \\
\text { segment) }\end{array}$ & $\begin{array}{l}-0.657 \\
{[0.470]}\end{array}$ & & $\begin{array}{l}-0.378 \\
{[0.498]}\end{array}$ & \\
\hline $\begin{array}{l}\text { Share of greenfield }{ }^{*} \text { before } \\
2001\end{array}$ & & $\begin{array}{r}3.475 \\
{[5.707]}\end{array}$ & & $\begin{array}{r}5.127 \\
{[5.633]}\end{array}$ \\
\hline $\begin{array}{l}\text { Share of greenfield }{ }^{*} \text { after } \\
2001\end{array}$ & & $\begin{array}{r}2.164 \\
{[5.586]}\end{array}$ & & $\begin{array}{r}13.789^{* * *} \\
{[4.818]}\end{array}$ \\
\hline $\begin{array}{l}\text { Share of takeover* before } \\
2001\end{array}$ & & $\begin{array}{r}-0.972 \\
{[0.631]}\end{array}$ & & $\begin{array}{r}-0.329 \\
{[0.509]}\end{array}$ \\
\hline $\begin{array}{l}\text { Share of takeover* after } \\
2001\end{array}$ & & $\begin{array}{r}-0.136 \\
{[1.108]}\end{array}$ & & $\begin{array}{l}-1.299 \\
{[1.344]}\end{array}$ \\
\hline ROA & $\begin{array}{r}1.401 \\
{[3.816]}\end{array}$ & $\begin{array}{r}1.584 \\
{[3.801]}\end{array}$ & $\begin{array}{l}-5.183^{*} \\
{[2.913]}\end{array}$ & $\begin{array}{l}-5.381^{*} \\
{[2.909]}\end{array}$ \\
\hline Cost & $\begin{array}{r}-115.361^{* * *} \\
{[31.760]}\end{array}$ & $\begin{array}{r}-114.849^{* \star *} \\
{[31.456]}\end{array}$ & $\begin{array}{l}-68.393^{*} \\
{[34.312]}\end{array}$ & $\begin{array}{l}-68.657^{*} \\
{[34.354]}\end{array}$ \\
\hline Capitalization & $\begin{array}{r}0.040 \\
{[0.636]}\end{array}$ & $\begin{array}{r}0.006 \\
{[0.635]}\end{array}$ & $\begin{array}{r}-1.613^{* *} \\
{[0.774]}\end{array}$ & $\begin{array}{r}-1.659^{* *} \\
{[0.758]}\end{array}$ \\
\hline Bank size & $\begin{array}{l}-0.144 \\
{[0.118]}\end{array}$ & $\begin{array}{r}-0.148 \\
{[0.119]}\end{array}$ & $\begin{array}{r}-0.260^{* * *} \\
{[0.096]}\end{array}$ & $\begin{array}{r}-0.264^{* * *} \\
{[0.097]}\end{array}$ \\
\hline NPL & $\begin{array}{r}-0.260^{* * *} \\
{[0.083]}\end{array}$ & $\begin{array}{r}-0.261^{* * *} \\
{[0.082]}\end{array}$ & $\begin{array}{r}-0.372^{* * *} \\
{[0.090]}\end{array}$ & $\begin{array}{r}-0.374^{* * *} \\
{[0.089]}\end{array}$ \\
\hline GDP & $\begin{array}{l}-0.241 \\
{[1.506]}\end{array}$ & $\begin{array}{r}0.255 \\
{[1.949]}\end{array}$ & $\begin{array}{r}0.973 \\
{[1.209]}\end{array}$ & $\begin{array}{l}-0.099 \\
{[1.407]}\end{array}$ \\
\hline Inflation & $\begin{array}{l}-3.407 \\
{[6.503]}\end{array}$ & $\begin{array}{r}2.817 \\
{[7.268]}\end{array}$ & $\begin{array}{l}9.807^{*} \\
{[5.724]}\end{array}$ & $\begin{array}{r}8.467 \\
{[6.747]}\end{array}$ \\
\hline Real interest rate & $\begin{array}{l}-3.464 \\
{[7.792]}\end{array}$ & $\begin{array}{l}-0.204 \\
{[7.442]}\end{array}$ & $\begin{array}{l}11.553 \\
{[7.289]}\end{array}$ & $\begin{array}{r}12.179^{*} \\
{[7.057]}\end{array}$ \\
\hline $\begin{array}{l}\text { Observations } \\
\text { Number of banks }\end{array}$ & $\begin{array}{r}775 \\
54\end{array}$ & $\begin{array}{r}775 \\
54\end{array}$ & $\begin{array}{r}781 \\
54\end{array}$ & $\begin{array}{r}781 \\
54\end{array}$ \\
\hline R-squared & 0.237 & 0.239 & 0.361 & 0.363 \\
\hline
\end{tabular}

Table 9 presents the results of equation (3). The dependent variable is the log-odds ratio of the share of loans to private firms (model 1 and 2) and entrepreneurs (model 3 and 4) in domestic banks' portfolios. The table lists coefficients and standard errors (in parentheses) from regression with pooled OLS with robust standard errors clustered on banks. All dependent variables except for ownership dummy are lagged by one quarter.

Regressions include seasonal dummies. Definitions of variables are provided in Table 1. ${ }^{\star \star \star},{ }^{\star \star}$, and " correspond to $1 \%, 5 \%$ and $10 \%$ significance levels, respectively. 
Table 10. Domestic Banks: Nonperforming Loans for Private Firms and Entrepreneurs

\begin{tabular}{|c|c|c|c|c|}
\hline & $\begin{array}{c}\text { Private } \\
\text { (transparent) } \\
\end{array}$ & $\begin{array}{c}\text { Private } \\
\text { (transparent) }\end{array}$ & $\begin{array}{l}\text { Entrepreneurs } \\
\text { (opaque) }\end{array}$ & $\begin{array}{l}\text { Entrepreneurs } \\
\text { (opaque) }\end{array}$ \\
\hline State-owned & $\begin{array}{r}-0.247 \\
{[0.278]}\end{array}$ & $\begin{array}{r}-0.248 \\
{[0.275]}\end{array}$ & $\begin{array}{l}-0.127 \\
{[0.405]}\end{array}$ & $\begin{array}{l}-0.134 \\
{[0.400]}\end{array}$ \\
\hline $\begin{array}{l}\text { Share greenfield (in this } \\
\text { segment) }\end{array}$ & $\begin{array}{r}4.875 \\
{[5.135]}\end{array}$ & & $\begin{array}{l}9.518^{* *} \\
{[4.368]}\end{array}$ & \\
\hline $\begin{array}{l}\text { Share takeover (in this } \\
\text { segment) }\end{array}$ & $\begin{array}{l}-0.988^{*} \\
{[0.531]}\end{array}$ & & $\begin{array}{r}0.057 \\
{[0.478]}\end{array}$ & \\
\hline $\begin{array}{l}\text { Share of greenfield }{ }^{*} \text { before } \\
2001\end{array}$ & & $\begin{array}{r}4.353 \\
{[4.588]}\end{array}$ & & $\begin{array}{r}7.934 \\
{[4.826}\end{array}$ \\
\hline Share of greenfield* after 2001 & & $\begin{array}{r}17.052^{* * *} \\
{[6.387]}\end{array}$ & & $\begin{array}{l}21.349^{* \star} \\
{[10.042}\end{array}$ \\
\hline Share of takeover* before 2001 & & $\begin{array}{l}-1.007^{*} \\
{[0.576]}\end{array}$ & & $\begin{array}{r}-0.024 \\
{[0.537]}\end{array}$ \\
\hline Share of takeover* after 2001 & & $\begin{array}{r}-2.068^{\star *} \\
{[0.874]}\end{array}$ & & $\begin{array}{l}-1.160 \\
{[1.079}\end{array}$ \\
\hline GDP & $\begin{array}{r}1.057 \\
{[1.133]}\end{array}$ & $\begin{array}{r}0.160 \\
{[0.961]}\end{array}$ & $\begin{array}{r}0.583 \\
{[1.015]}\end{array}$ & $\begin{array}{r}-0.043 \\
{[1.068}\end{array}$ \\
\hline Inflation & $\begin{array}{r}-14.256^{*} \\
{[7.280]}\end{array}$ & $\begin{array}{r}-13.021^{*} \\
{[6.786]}\end{array}$ & $\begin{array}{r}-9.716 \\
{[8.918]}\end{array}$ & $\begin{array}{l}-9.250 \\
{[7.674}\end{array}$ \\
\hline Real interest rate & $\begin{array}{r}-14.394 \\
{[8.917]}\end{array}$ & $\begin{array}{r}-11.131 \\
{[7.401]}\end{array}$ & $\begin{array}{r}-11.404 \\
{[11.238]}\end{array}$ & $\begin{array}{r}-8.413 \\
{[8.524}\end{array}$ \\
\hline $\begin{array}{l}\text { Observations } \\
\text { Number of banks }\end{array}$ & $\begin{array}{r}847 \\
56\end{array}$ & $\begin{array}{r}847 \\
56\end{array}$ & $\begin{array}{r}847 \\
56\end{array}$ & $\begin{array}{r}847 \\
56\end{array}$ \\
\hline R-squared & 0.030 & 0.036 & 0.025 & 0.031 \\
\hline
\end{tabular}

Table 10 presents the results of equation (4). The dependent variable is the ratio of nonperforming loans to total loans for private firms (model 1 and 2) and entrepreneurs (model 3 and 4), calculated as a deviation from the median. The table lists coefficients and standard errors (in parentheses) from regression with pooled OLS with robust standard errors clustered on banks. All dependent variables except for ownership dummy are lagged by one quarter. Regressions include seasonal dummies. Definitions of variables are provided in Table 1. ${ }^{\star * *}$, , and correspond to $1 \%, 5 \%$ and $10 \%$ significance levels, respectively. 


\section{References}

Ayyagari, M., Beck, T., and A. Demirguc-Kunt, 2007, "Small and Medium Enterprises Around the Globe," Small Business Economics, Vol. 29, pp. 415-434.

Beck, N., and Katz, J.N, 1995, "What to Do (and not to Do) with Time-Series Cross-Section Data," American Political Science Review, Vol. 89, pp. 634-647.

Beer, C., S. Ongena, and M. Peter, 2008, “Taking the Currency Bet': Austrian Households as Carry Traders," mimeo.

Berger, A., N., and G. F. Udell, 2006, "A More Complete Conceptual Framework for SME Finance," Journal of Banking and Finance, Vol. 30 (11), pp. 2945-2966.

Berger, A., N. Miller, M. Petersen, R. Rajan, and J. Stein, 2005, “Does Function Follow Organizational Form? Evidence from the Lending Practices of Large and Small Banks," Journal of Financial Economics, Vol. 76, pp. 237-269.

Berger, A., L. Klapper, and G. Udell, 2001, "The Ability of Banks to Lend to Informationally Opaque Small Businesses," Journal of Banking and Finance, Vol. 25 (12), pp. 21272167.

Berger, A., R. DeYoung, H. Genay, and G. Udell, 2000, “Globalization of Financial Institutions: Evidence from Cross-Border Banking Performance," BrookingsWharton Papers on Financial Services, Vol. 3.

Berger, A., A. Saunders, J. Scalise, and G. Udell, 1998, “The Effects of Bank Mergers and Acquisitions on Small Business Lending," Journal of Financial Economics Vol. 50, pp. 187-229.

Bonin, J.P., Hasan, I., and Wachtel, P., 2005, "Bank Performance, Efficiency and Ownership in Transition Countries," Journal of Banking and Finance, Vol. 29 (1), 31-53.

Brown, M., S. Ongena, and P. Yesin, 2008, “Currency Denomination of Bank Loans: Evidence from Small firms in Transition Countries," Tilburg University, Center for Economic Research, Discussion Paper No. 16.

Calvo, G.A., and F. Coricelli, 1993, "Output Collapse in Eastern Europe. The Role of Credit,” IMF Staff Papers, International Monetary Fund, Vol. 40, pp. 32-52.

Claeys, S., and C. Hainz, 2007, “Acquisition versus Greenfield: the Impact of the Mode of Foreign Bank Entry on Information and Bank Lending Rates," mimeo. 
Clarke, G., R. Cull, and M. S. Martinez Peria, 2006, "Foreign Bank Participation and Access to Credit across Firms in Developing Countries," Journal of Comparative Economics, Vol. 34(4), pp. 774-795.

Clarke, G., R. Cull, M. Soledad Martinez Peria, and S. Sánchez, 2005, "Bank Lending to Small Businesses in Latin America: Does Bank Origin Matter?" Journal of Money, Credit and Banking, Vol. 37 (1), pp. 83-118.

De Haas, R, and I. Naaborg, 2006, "Foreign Banks in Transition Countries: To Whom do They Lend and How are they Financed?" Financial Markets, Institutions \& Instruments, Vol. 15 (4), pp. 159-199.

De Haas, R, and Van Lelyveld, I., 2006, "Foreign Banks and Credit stability in Central and Eastern Europe: A Panel Data Analysis," Journal of Banking and Finance, Vol. 30 (7), pp. 1927-1952.

de la Torre, A., M. S. Martnez Pera, and S. Schmukler, 2008, "Bank Involvement with SMEs: Beyond Relationship Lending," mimeo.

Dell'Ariccia, G., and R. Marquez, 2004, "Information and Bank Credit Allocation," Journal of Financial Economics, Vol. 72, pp. 185-214.

Detragiache, E., Tressel, T., and P. Gupta, 2008, "Foreign Banks in Poor Countries: Theory and Evidence," Journal of Finance, Vol. 63 (5), pp. 2123-21260.

Dooley, M. P., and I. Shin, 2000, "Private Inflows When Crises are Anticipated: a Case Study of Korea,” NBER Working Paper No. 7992 (Cambridge, Massachusetts: National Bureau of Economic Research).

European Central Bank, 2006, EU Banking Sector Stability, November 2006.

Giannetti, M., and S. Ongena, 2008a, "Financial Integration and Firm Performance: Evidence from Foreign Bank Entry in Emerging Markets," Review of Finance forthcoming.

Giannetti M., and S. Ongena, 2008b, "Lending by Example": Direct and Indirect Effects of Foreign Banks in Emerging Markets," mimeo.

Gormley, T., 2007a, "Costly Information, Foreign Entry, and Credit Access,” mimeo.

Gormley, T., 2007b, "The Impact of Foreign Bank Entry in Emerging Markets: Evidence from India," mimeo. 
Gottesman A., and G. S. Roberts, 2004, "Maturity and Corporate Loan Pricing," The Financial Review, Vol. 39 (1), pp. 55-77.

Hainz, C., 2005, "Effects of Bank Insolvency on Corporate Incentives in Transition Economies," Economics of Transition, Vol. 13, No. 2, pp. 261-286, (April 2005), (Munich, Germany: Institute for Economics Research).

Hadri, K., 2000, “Testing for Stationarity in Heterogeneous Panel Data," The Econometrics Journal, Vol. 3, pp. 148-161.

Hallberg, K., 2001, “A Market-Oriented Strategy for Small and Medium-Scale Enterprises," International Finance Corporation Discussion Paper No. 40.

Havrylchyk, O., and E. Jurzyk, 2007, "Profitability of Foreign Banks in Central and Eastern Europe: Does the Mode of Entry Matter?" mimeo.

Havrylchyk, O, 2006, "Efficiency of the Polish Banking Industry: Foreign Versus Domestic Banks," Journal of Banking and Finance, Vol. 30 (7), pp. 1975-1996.

Helwege, J., and C. Turner, 1999, "The Slope of the Credit Yield Curve for SpeculativeGrade Issuers," Journal of Finance, Vol. 54, pp. 1869-1884.

Im, K. S., M. H. Pesaran, and Y. Shin, 2003, "Testing for Unit Roots in Heterogeneous Panels", Journal of Econometrics, Vol. 115, pp. 53-74.

Khwaja, A. I., and Mian, A., 2005, "Do Lenders Favor Politically Connected Firms? Rent Provision in an Emerging Financial Market," Quarterly Journal of Economics, Vol. 120 (4), pp. 1371-1412

La Porta, R., and F. Lopez-De-Silanez, 2002, "Government Ownership of Banks," Journal of Finance, Vol. 57, No. 1, pp. 265-301.

Levin, A., C.-F Lin, and J. C. Chia-Shang, 2002, "Unit Root Tests in Panel Data: Asymptotic and Finite Sample Properties," Journal of Econometrics, Vol. 108, pp. 1-24.

Levine, R., 2005, "Finance and Growth: Theory and Evidence," in Philippe Aghion, and Steven N. Durlauf (eds.) Handbook of Economic Growth, North Holland, Amsterdam, pp. 865-934.

Maddala, G.S., and S. Wu, 1999, "A Comparative Study of Unit Root Tests With Panel Data and A New Simple Test," Oxford Bulletin of Economics and Statistics, Vol. 61, pp. $631-652$. 
Martinez Peria, M. S., and Mody, A., 2004, "How Foreign Participation and Market Concentration Impact Bank Spreads: Evidence from Latin America," Journal of Money, Credit and Banking, Vol. 36 (3), pp. 511-537.

Mester, L. 1997, “What's the Point of Credit Scoring?” Federal Reserve Bank of Philadelphia Business Review, pp. 3-16.

Mian, A., 2006, "Foreign, Private Domestic, and Government Banks: New Evidence from Emerging Markets," Journal of Banking and Finance (forthcoming).

Ortiz-Molina, H., and F. Penas, 2008 "Lending to Small business: The Role of Loan Maturity in Addressing Information Problems," Small Business Economics, Vol. 30 (4), pp. $316-383$.

Petersen, M., 2004, "Information: Hard and Soft," mimeo.

Petersen, M., and R.G. Rajan, 2002, "Does Distance Still Matter? The Information Revolution in Small Business Lending," Journal of Finance, Vol. 57, pp. 2533-2570.

Pluemper T., and V.E. Troeger, 2007, "Efficient Estimation of Time-Invariant and Rarely Changing Variables in Finite Sample Panel Analyses with Unit Fixed Effects," Political Analysis, Vol. 15:2, pp. 124-139.

Rodrik, D., and Velasco, A., 1999, "Short-Term Capital Flows," in 'Annual World Bank Conference on Development Economics 1999', World Bank.

Sapienza, P., 2004, “The Effects of Government Ownership on Bank Lending," Journal of Financial Economics, Vol. 2, pp. 357-384

Sengupta, R., 2007, "Foreign Entry and Bank Competition," Journal of Financial Economics, Vol. 84, pp. 502-528.

Shleifer, A., and R. Vishny, 1998, “The Grabbing Hand: Government Pathologies and their Cures," Harvard University Press, (Cambridge, Massachussetts).

Sorsa, P., Bakker, B., Duenwald, C., Maechler, A., and Tiffin, A., 2007, "Vulnerabilities in Emerging Southeastern Europe-How Much Cause for Concern?” IMF Working Paper No. 07/236, (Washington: International Monetary Fund).

Stein, J.C., 2002, "Information Production and Capital Allocation: Decentralized vs. Hierarchical Firms," Journal of Finance, Vol. 57, pp. 1891-1921. 
Stiglitz, J., 1993, "The Role of State in Financial Markets," Proceedings of the World Bank Annual Conference on Economic Development, pp. 19-56, (Washington D.C., World Bank).

Weill, L., 2003, "Banking Efficiency in Transition Economies: The Role of Foreign Ownership," Economics of Transition, Vol. 11 (3), pp. 569-592. 